\title{
A Multi-Compartment Hybrid Computational Model Predicts Key Roles for Dendritic Cells in Tuberculosis Infection
}

\author{
Simeone Marino and Denise E. Kirschner* \\ Department of Microbiology and Immunology, University of Michigan Medical School, \\ Ann Arbor, MI 48109, USA; simeonem@umich.edu \\ * Correspondence: kirschne@umich.edu; Tel.: +1-734-647-7722
}

Academic Editors: Gennady Bocharov, Olga Solovyova and Vitaly Volpert Received: 25 August 2016; Accepted: 7 October 2016; Published: 21 October 2016

\begin{abstract}
Tuberculosis (TB) is a world-wide health problem with approximately 2 billion people infected with Mycobacterium tuberculosis (Mtb, the causative bacterium of TB). The pathologic hallmark of Mtb infection in humans and Non-Human Primates (NHPs) is the formation of spherical structures, primarily in lungs, called granulomas. Infection occurs after inhalation of bacteria into lungs, where resident antigen-presenting cells (APCs), take up bacteria and initiate the immune response to Mtb infection. APCs traffic from the site of infection (lung) to lung-draining lymph nodes (LNs) where they prime $\mathrm{T}$ cells to recognize $\mathrm{M} t b$. These $\mathrm{T}$ cells, circulating back through blood, migrate back to lungs to perform their immune effector functions. We have previously developed a hybrid agent-based model (ABM, labeled GranSim) describing in silico immune cell, bacterial (Mtb) and molecular behaviors during tuberculosis infection and recently linked that model to operate across three physiological compartments: lung (infection site where granulomas form), lung draining lymph node (LN, site of generation of adaptive immunity) and blood (a measurable compartment). Granuloma formation and function is captured by a spatio-temporal model (i.e., ABM), while LN and blood compartments represent temporal dynamics of the whole body in response to infection and are captured with ordinary differential equations (ODEs). In order to have a more mechanistic representation of APC trafficking from the lung to the lymph node, and to better capture antigen presentation in a draining LN, this current study incorporates the role of dendritic cells (DCs) in a computational fashion into GranSim. Results: The model was calibrated using experimental data from the lungs and blood of NHPs. The addition of DCs allowed us to investigate in greater detail mechanisms of recruitment, trafficking and antigen presentation and their role in tuberculosis infection. Conclusion: The main conclusion of this study is that early events after Mtb infection are critical to establishing a timely and effective response. Manipulating CD8+ and CD4+ T cell proliferation rates, as well as DC migration early on during infection can determine the difference between bacterial clearance vs. uncontrolled bacterial growth and dissemination.
\end{abstract}

Keywords: agent-based model; multi-compartmental model; tuberculosis; dendritic cells; uncertainty and sensitivity analysis

\section{Introduction}

Tuberculosis (TB) remains one of the main causes of death world-wide and the leading cause due to an infectious disease [1]. For such an ancient disease, it is surprising that so little is still known about what provides a protective response against infection with Mycobacterium tuberculosis (Mtb), the causative agent. When infection occurs with $\mathrm{Mtb}$, two main outcomes are observed. One is active disease where the host is unable to contain infection, which if left untreated results in death of the 
host (about 5\%-10\% of those infected). Active disease can occur directly after infection (primary TB), after reactivation (see below) or in the case of re-exposure (which is probably the most common pathway leading to disease in highly endemic countries). The difference between re-exposure and re-activation likely plays a role in the immune response observed. The second outcome is latent infection. This occurs when the host controls infection, which remains clinically latent even though bacteria are still harbored (about $90 \%$ of infected) [2]. Latent infection can become reactivated if the host is compromised in some way leading to active disease. There is still no efficacious vaccine against Mtb, although 30 vaccines are in various stages of testing and clinical trials (http://www.aeras.org/). Long regimens of antibiotics (6-9 months) with multiple drugs are needed to control infection. Antibiotics also represent a double-edged sword, since they lead to Mtb resistance (which is rapidly increasing), especially due to long time regimens that are naturally associated with non-compliance. New treatment and prevention strategies are desperately needed to make a major impact on TB morbidity and mortality. However, the host-pathogen interactions occurring during Mtb infection are complex and span across multiple biological scales, ranging from bacterial and cellular to organ to an entire host, making research on TB challenging.

When Mtb bacteria are inhaled into lungs, they are taken up by two types of lung resident immune cells that are known generally as antigen-presenting cells (APCs): these are macrophages (MФs) and dendritic cells (DCs). Mtb is preferentially an intracellular pathogen, however their growth rate is extremely slow compared to most bacteria (days rather than minutes). APCs are typically unable to kill Mtb unless they are in a highly activated state, and thus bacteria grow and burst out of these cells, killing their host cell; and are taken up by new APCs. This process continues, leading to the development of the hallmark of Mtb infection: a granuloma. Granulomas are a collection of host immune cells (e.g., macrophages, DCs and T cells) together with bacteria and infected cells, with a centralized necrotic region. It is presumed that the organization is an attempt to contain or eliminate the infection, but Mtb have evolved mechanisms that permit survival within granulomas. Within a single host, several granulomas form in response to the initial infection dose, and these granulomas are heterogeneous with variable trajectories, complicating the study of this infection [3-5]. For example, in some hosts none of the granulomas are successful at controlling bacterial replication, and those that fail lead to a pattern of dissemination and new granuloma formation, resulting in lung destruction and active TB. In other hosts, granulomas can all be successful and the host can develop latent infection. Thus infection dynamics play out at the scale of granuloma. T cells play a central role in protection against TB [6-11], as best exemplified by the dramatic susceptibility of HIV+ humans to TB, even in the early stages of HIV infection [12-14]. Other immune cells are increasingly shown to play key roles in the immune dynamics of Mtb infection and T cells are interdependent on their dynamics.

What has received far less attention are the cells of the early immune response in Mtb infection, e.g., DCs, and it is likely that these cells bridge to long-term immunity in important and key ways. Figure 1 shows how dynamics occurring in lungs, lymph nodes and blood are dynamically linked and each participates in the host-pathogen interactions describing Mtb infection. Most experimental studies focus on a single biological (length and/or time) scale of interest, e.g., examination of immune cells in blood or a particular signaling pathway. To truly understand the complex in vivo immune response to $\mathrm{Mtb}$, it is important to integrate information from experiments performed at multiple scales and over multiple physiological compartments (lung, blood, lymphatics, and lymph nodes). To address this complex disease we thus need a comprehensive and integrative tool to generate testable hypotheses about what characterizes an effective immune response to Mtb infection. We use a mathematical and computational modeling approach to identify key features of the host immune system that can serve as targets for control of infection. We focus specifically on the role of dendritic cells as they serve as the link between physiological compartments of lungs and lymph nodes (LNs) that generate activated immune cells that can traffic to lung granulomas to aid in infection control. 


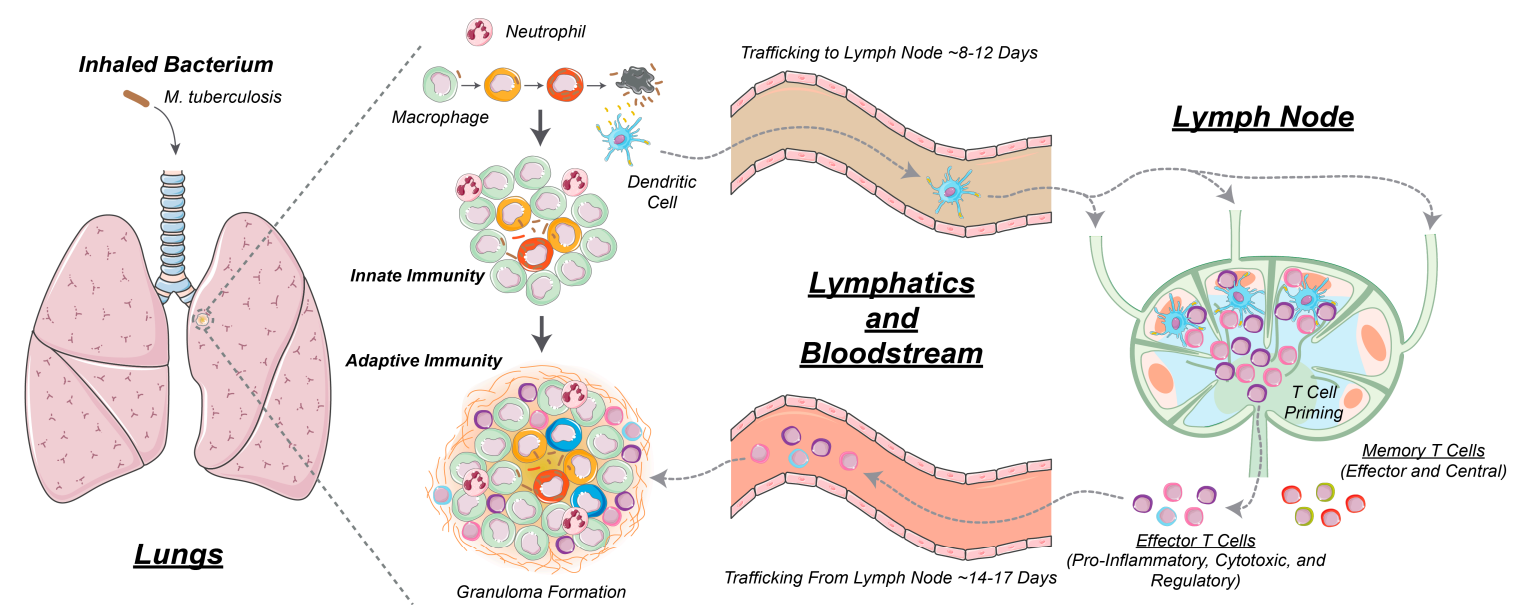

Figure 1. Overview of the immune response to Mycobacterium tuberculosis (Mtb) infection. Infection begins in lungs and antigen-presenting cells (APCs) such as dendritic cells (DCs) take up Mtb and then traffic from lungs to lung draining lymph nodes (LNs) where they prime $\mathrm{T}$ cells via the process of antigen presentation. This occurs when pieces of Mtb (called antigens) are presented on the surface of dendritic cells (DCs) to $\mathrm{T}$ cells to activate $\mathrm{T}$ cells. These $\mathrm{T}$ cells migrate back to the lungs via blood, and participate in granuloma formation and function, including functions such as activation of macrophages to kill their intracellular Mtb $[9,15]$. Some T cell subsets that have been primed by DCs (cytotoxic CD8+ T cells) can kill infected macrophages directly $[11,16,17]$.

Mathematical/computational models are powerful tools for deciphering the outcomes of multiple simultaneous, nonlinear processes. In particular, agent-based models (ABMs) link molecular and cellular behavior-and therapeutic interventions aimed at molecules and cells-with tissue scale outcomes, such as a growing or stable granulomas or containment of infection. Excellent reviews on ABMs can be found in [15-18]. Because we are interested in individual cellular behavior, ABMs are the appropriate modeling type here.

While we have modeled the host-Mtb response using non-linear ordinary differential equation (ODE) systems [19-23], we and others have built ABMs that capture both the spatial and temporal dynamics of granuloma formation in the lung [20,22,24-28]. Our modeling framework, GranSim, focuses on immune dynamics in the context of bacterial dynamics is a hybrid agent-based model (for full details see [29]). We have used GranSim to explore drug treatment during Mtb infection [30-32] and performed virtual clinical trials to predict optimal treatment strategies [30-35]. Here we explore a version of GranSim that is multi-compartment, where the hybrid ABM is connected to two non-linear systems of ODEs tracking compartmental models capturing dynamics of blood and lung draining LNs. This multi-compartment model was recently used to explore the existence of biomarkers for TB [36]. However in that model, we only had a mathematical phenomenological proxy for APCs moving from the lung to the LN and similarly a probability function capturing recruitment of T cells from the LN back to the granuloma. Here, we replace the phenomenological expressions for these processes by explicitly including DCs in the lung model GranSim, and tracking their trafficking from lung to LN where they orchestrate priming of $\mathrm{T}$ cells. We use our sensitivity and uncertainty analyses techniques to analyze the 3-compartmental hybrid system and identify which mechanisms are driving different granuloma outcomes in the lung [37]. In addition, we derive a way to scale our single granuloma lung model to a whole host scale so that we are not only able to calibrate our model with data, but also so we are able to compare our results with data derived from non-human primates (NHP) as we have done previously [36]. Our predictions can be used to predict how certain treatments could improve infection outcomes. 


\section{Materials and Methods}

\subsection{GranSim: Computational Model of Granuloma Formation and Function in the Lung}

The pathologic hallmark of Mycobacterium tuberculosis (Mtb) infection in humans and NHPs is the formation of spherical structures, primarily in the lungs, called granulomas. Infection occurs after inhalation of Mtb into the lungs. Resident antigen presenting cells (APCs) such as MФs and DCs, take up Mtb and initiate granuloma formation. DCs traffic to lung-draining LNs where T lymphocytes are primed. These $\mathrm{T}$ lymphocytes migrate to the lung and participate in granuloma formation and function (see Figure 1). We have developed a hybrid agent-based model (ABM, labeled GranSim) describing in silico cellular (i.e., macrophages and $\mathrm{T}$ cells), bacterial and molecular behaviors during Mtb infection in three physiological compartments: lung (site of infection), draining lymph node (LN, site of generation of adaptive immunity) and blood (a measurable compartment) [36].

Our computational model captures single granuloma formation and function in the lung $[24,25,38,39]$, while LN and blood compartments $[19,40]$ represent dynamics of the whole body in response to infection, i.e., we assume they are well-mixed compartments.

GranSim captures cellular recruitment to lungs, chemotaxis of cells, changes of cell states (activation, infection, etc.), cytokine and chemokine secretion, as well as effector $\mathrm{T}$ cell functions $[24,25,38,39,41]$. Probabilistic interactions between immune cells and bacterial populations are described by sets of rules between immune cells and $\mathrm{Mtb}$ in the lung that are updated based on new biological data [39,42,43]. We also capture multi-scale events, such as tumor necrosis factor (TNF) or interleukin-10 (IL-10) receptor/ligand binding and trafficking and intracellular signaling events with ordinary differential equations (ODEs) that are solved within each agent [38,39,41-43]. Diffusion of relevant chemokines and cytokines is performed by solving the relevant partial differential equations (PDEs) [44]. Each simulation follows events over several hundred days, building over time to track thousands of individual cells (agents). Based on our recent work [32], we represent the section of lung tissue where granuloma typically develops with a larger spatial grid $(4 \times 4 \mathrm{~mm})$ to better capture physiological granuloma sizes (with mean and standard deviation of 2 and $0.5 \mathrm{~mm}$, respectively, on a collection of $\sim 500$ granulomas, see [32] for details). This new, larger grid size comprises a collection of $200 \times 200$ micro-compartments sized to a macrophage diameter of $\sim 20 \mathrm{~mm}$. All of the rules and an executable file for GranSim can be found at [29].

\subsection{Multi-Compartment Gransim: Tracking Cell Dynamics in the Lymph Node and Blood}

Our unique multi-scale and multi-physiological compartmental, hybrid computational model generates in silico data on dynamics of infection in both blood and lymph node, capturing formation of independent granulomas in lungs and at the same time $\mathrm{T}$ cell profiles in blood. In a recent study [36], we easily captured LN and blood dynamics using a compartmentalized system of non-linear 31 ordinary differential equations (ODEs), where we tracked CD4+ and CD8+ T cells with different memory classes (i.e., Naïve, Effector, Central and Effector Memory), both Mtb-specific and non Mtb-specific. Mtb-specific T cells represent a generic class of antigen-specific $\mathrm{T}$ cells, assuming that all Mtb-specific antigens are equally immune-responsive. This system of ODEs can be found in the Supplementary File 1.

\subsection{Adding DCs to GranSim}

In order to have a better representation of APC trafficking from the lung to the lymphatics, herein we added a new class of cells to GranSim, namely dendritic cells (DCs). DCs are considered professional APCs, since their main task is to sample tissues and blood for foreign cells/non-self particles/antigen and, when needed, to traffic to specific organ draining lymph nodes to initiate a specific immune response by presenting their findings to $\mathrm{T}$ cells. The initial number of resident DCs in lungs is based on a fraction (percentOfMacInitNumber) of resident macrophages in the lung, and consequently on the grid. These numbers are calibrated from experimental staining of healthy 
lung tissues in our previous studies [20,22]. DC recruitment to the lungs is executed with a random probability of percentOfMacInitNumber. Once on the grid, we assume that a DC moves and secretes cytokines and chemokines similarly to [45,46].

The first major difference between macrophages and DCs in our model is that macrophages can take up Mtb and kill their intracellular load, while it has been shown that DCs do not kill their intracellular burden [47-49]. Macrophages can do this task more efficiently when stimulated by cytokines such as INF- $\gamma$. Another major difference between macrophage and DC dynamics in our model is that once a DC interacts directly (or indirectly) with Mtb antigens, it is labeled as "stimulated". Mtb antigen stimulation can occur in the following ways: (i) DCs uptake Mtb; (ii) Infected Macs are in the DC in the Moore Neighborhood (i.e., defined as the grid spaces on a two-dimensional square lattice that are composed of a central grid space and the eight grid spaces that surround it) [50]; (iii) Extracellular Mtb are in the Moore Neighborhood of a DC and (iv) Dead Mtb are in the Moore Neighborhood (i.e., the surrounding 8 grid compartments of a given grid space in the ABM) of the DC.

Once DCs are stimulated, a parameter determines the time of DC exit from the lung and allows it to migrate into the lymphatics (exitInterval), which is the conduit to the draining LN. In contrast, macrophages never exit the grid, they can only die (via age or by being killed a number of different ways (Apoptosis, induced cell death by cytoxic $T$ cells, etc.). The lymphatics are represented in the model as a virtual compartment to mimic spatial delays during DC trafficking from the site of infection to the LN. After exiting the lung, DCs are placed in a queue, where another parameter (exitToLN) tracks the physiological delay observed for DCs to reach the draining lymph node. This delay is observed on average to be about a few days to a week in most infections [51]. Once in the LN, DCs perform antigen presentation leading to $\mathrm{T}$ cell priming and activation as described in $[19,36]$.

\subsection{Scaling to Host Feature}

When a host is infected with Mtb, not one, but a large number of granulomas form in the lungs over time. The median number of granulomas at 4 weeks was $46 \pm 21$ (range 13-97, $n=14$ monkeys) [52]. This number is due to the bacterial dose that the host receives, and also the ability of bacteria to disseminate in the lung. GranSim currently captures granuloma formation and function of a single granuloma during TB infection in the lung. We now explicitly introduce a scaling factor (i.e., scaling $M D C$ ) to capture TB infection in the whole lung. In other words, we multiply the number of DCs migrating to the LN from our single granuloma model by scalingMDC to represent multiple granulomas draining DCs into the LN. This larger number of DCs is then passed to the ODE system representing the LN-Blood compartments, where the DC Equation (S1) is pulsed accordingly (see more details below). We calibrate this scaled GranSim (that is coupled to the LN and blood ODE model) to experimental data derived in the lung and the blood for each non-human primate (NHP). The blood data is available longitudinally, while the lung data is taken from many different NHP at the time of death (necropsy) over different time, that we collate into a time series (see section below on NHP data for a full explanation and also [19]).

We assume that the majority of the granulomas found in the lung at necropsy (i.e., the parameter scaling $M D C$ ) have developed at the time of initial infection. The scaling to host step is performed by multiplying the number of stimulated DCs in our in silico granuloma by scalingMDC. The resulting quantity pulses Equation (S1) of the system of ODEs, namely the equation capturing DC dynamics (see Supplementary File 1 for all the details on the equations cited in the manuscript).

Figure 2 shows an example of the scaling to host procedure with scaling $M D C=\mathbf{N}$. Antigen presentation (see Equations (S2) and (S11)) and T cell priming (see Equations (S3)-(S6) and (S12)-(S15)) are then performed in the lymph node compartment and many different $\mathrm{T}$ cell phenotypes are generated and migrate from LN into the blood. Some of these $\mathrm{T}$ cells traffic through blood and reach the site of infection. This is driven by chemokine gradients and many signals induced by infection and inflammation in the lung. Since we only model one granuloma in detail (i.e., GranSim), we recruit Effector-(E) and Effector Memory-(EM) T cells to GranSim first and update T cell levels in blood. Then, 
we perform recruitment $\mathrm{N}-1$ times to mimic recruitment in the remainder of the granulomas in the lung. Recruitment in these $\mathrm{N}-1$ granulomas is performed assuming similar recruitment conditions at their vascular sources. At the end of each recruitment step, the blood levels are updated reflecting the number of E- and EM-T cells that have successfully migrated to the other granulomas.
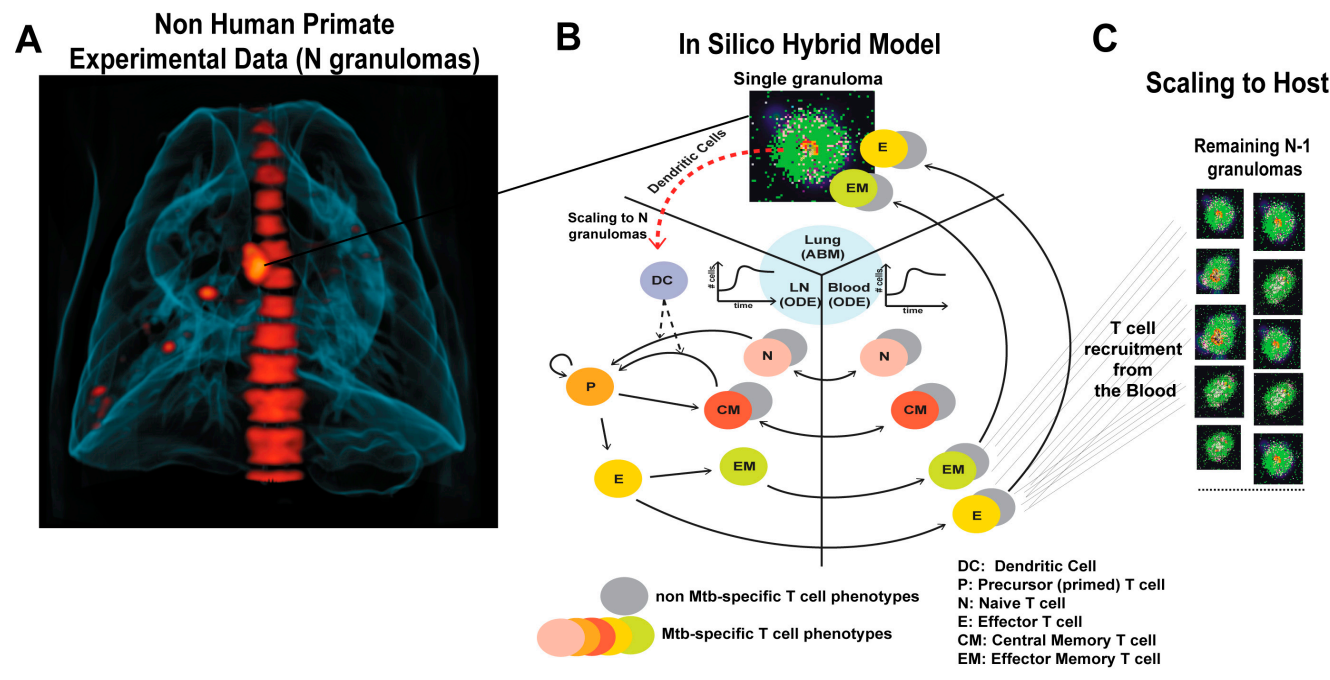

Figure 2. Scaling to host methodology. Our in silico model captures single granuloma formation in the lung. Panel (A) shows a PET-CT scan of the lung of an infected Non-Human Primate (NHP). An important and likely independent driver of $\mathrm{Mtb}$ infection outcome is inflammation. In vivo 18F-Fluorodeoxyglucose (FDG)-PET/CT signals are used to measure the extent of inflammation both in humans [3] and in non-human primates infected with Mtb [52,53]. PET-CT scan is an advanced nuclear imaging technique which combines positron emission tomography (PET) and computed tomography (CT) into one machine. A PET/CT scan reveals information about both the structure and function of cells and tissues in the body during a single imaging session. FDG is a PET probe that incorporates into metabolically active host cells. FDG avidity is calculated by standardized uptake values (SUVs), a measure of the metabolic activity of each granuloma and is corrected for granuloma size [53]. The red ("hot") spots represent inflammation within granulomas indicating a number of granulomas are present (image courtesy of Joanne Flynn lab). A diagram of our in silico multi-compartment hybrid model is shown in Panel (B). An Agent-Based Model captures formation of a single granuloma in the lung, while a system of 31 ordinary differential equations (ODEs) captures the lymph node coupled to the blood dynamics of the whole host. Panel (C) illustrates the scaling to host methodology implemented to capture recruitment to the other granulomas. Where $\mathrm{N}-1$ granuloma remain in the lung with the Nth being the one we model with GranSim.

\subsection{Uncertainty and Sensitivity Analysis}

We quantify the importance of each host mechanism involved directly and indirectly in the infection dynamics using statistical techniques known as uncertainty and sensitivity analyses. In our recent published review on uncertainty and sensitivity (US) analyses techniques [54], we showed how multidimensional parameter spaces can be globally sampled in a computationally efficient manner by Latin hypercube sampling (LHS) algorithms. Correlations between model output and parameter values can then be determined using Partial Rank Correlation Coefficient (PRCC), which varies between -1 (perfect negative association/correlation between model output and parameters) and +1 (perfect positive association/correlation between model output and parameters). A PRCC value of zero or close to zero can be interpreted as having no (significant) association/correlation between model output and parameters. Statistical tests are available to assess whether a PRCC is significantly different from 0, as well as if two PRCCs are significantly different (see [37] for a complete review). In this work we specifically address time-dependent correlations that can be tracked by plotting time 
courses of significant PRCCs with respect to many outputs classified as contributing to inflammation, infection, adaptive immune response and blood/lymph node factors. By combining both of these analysis tools [55-58], we guide our understanding as to how and what extent variability in model mechanisms captured by parameter values can affect infection outcomes in an ordered fashion. We have successfully used this approach in our previous studies, both equation-based (i.e., ordinary, partial and delay differential equation systems), as well as agent-based model settings [24,25,59-61].

Our computational model is a hybrid model which combines a deterministic system of ordinary differential equations with a stochastic agent-based model. Thus we need to address both epistemic (or subjective, reducible, type B uncertainty, see [62]) and aleatory (or stochastic, irreducible, type A) uncertainty (see $[37,62]$ for details). Epistemic uncertainty is driven by input/parameter variation, which is assumed to be constant throughout the in silico simulation. Aleatory uncertainty emerges anytime stochastic inputs/parameters are built into an in silico simulation. Thus, unless the random generator selects the same seed, a stochastic model will always generate different outcomes.

To address epistemic uncertainty we perform 1000 parameter sweeps (i.e., parameter samples), while aleatory uncertainty is addressed by performing 10 replications for each parameter sweep/combination. This yields 10,000 replications of the model that gives us a solid basis for analysis. We then calculate PRCCs with respect of the many outcomes under investigation on the mean of the 10 replicates to control for random effects and aleatory uncertainty.

Given the multi-compartmental nature of our system, detailed uncertainty and sensitivity (US) analyses were applied to our model to explore model dynamics both within the same compartment (intra-compartmental/intra-scale) and between different compartments or physiological scales (inter-compartmental/inter-scale). Here, we vary 50 parameters total: 8 initial conditions for $\mathrm{T}$ cell memory phenotypes in the blood, 36 parameters in the LN-Blood compartment and 6 parameters in the lung compartment (see Tables 1 and 2 for the parameters varied and the ranges we used).

Table 1. Initial conditions. These values are based on the experimental data collected and published in our previous work [36]. The values and references for the scaling parameters (i.e., $\alpha, \lambda$ and host_LN (lymph node)) are given in Appendix A.

\begin{tabular}{|c|c|c|c|}
\hline Variable & Value & Units & Description \\
\hline $\mathrm{APC}$ & 0 & Cell count & Antigen presenting cell proxy in the lymph node \\
\hline $\mathrm{N}_{\mathrm{Ln}, 4}$ & $\mathrm{~N}_{\mathrm{B}, 4} \times(\alpha /$ host_Ln $)$ & Cell count & Mtb-specific LN Naïve CD4+ T cell \\
\hline$P_{\mathrm{Ln}, 4}$ & 0 & Cell count & Mtb-specific LN Precursor CD4+ T cell \\
\hline $\mathrm{EM}_{\mathrm{Ln}, 4}$ & 0 & Cell count & Mtb-specific LN Effector Memory CD4+ T cell \\
\hline $\mathrm{CM}_{\mathrm{Ln}, 4}$ & 0 & Cell count & Mtb-specific LN Central Memory CD4+ T cell \\
\hline $\mathrm{N}_{\mathrm{B}, 4}$ & {$[255,610] \times \lambda$} & Cell $/ \mathrm{mm}^{3}$ & Mtb-specific Blood Naïve CD4+ T cell \\
\hline $\mathrm{E}_{\mathrm{B}, 4}$ & 0 & Cell $/ \mathrm{mm}^{3}$ & Mtb-specific Blood Effector CD4+ T cell \\
\hline $\mathrm{CM}_{\mathrm{B}, 4}$ & 0 & Cell $/ \mathrm{mm}^{3}$ & Mtb-specific Blood Central Memory CD4+ T cell \\
\hline $\mathrm{EM}_{\mathrm{B}, 4}$ & 0 & Cell $/ \mathrm{mm}^{3}$ & Mtb-specific Blood Effector Memory CD4+ T cell \\
\hline $\mathrm{N}_{\mathrm{Ln}, 8}$ & $\mathrm{~N}_{\mathrm{B}, 8} \times(\alpha /$ host_Ln $)$ & Cell count & Mtb-specific LN Naïve CD8+ T cell \\
\hline $\mathrm{P}_{\mathrm{Ln}, 8}$ & 0 & Cell count & Mtb-specific LN Precursor CD8+ T cell \\
\hline $\mathrm{EM}_{\mathrm{Ln}, 8}$ & 0 & Cell count & Mtb-specific LN Effector Memory CD8+ T cell \\
\hline $\mathrm{CM}_{\mathrm{Ln}, 8}$ & 0 & Cell count & Mtb-specific LN Central Memory CD8+ T cell \\
\hline $\mathrm{N}_{\mathrm{B}, 8}$ & {$[255,610] \times \lambda$} & Cell $/ \mathrm{mm}^{3}$ & Mtb-specific Blood Naïve CD8+ T cell \\
\hline $\mathrm{E}_{\mathrm{B}, 8}$ & 0 & Cell $/ \mathrm{mm}^{3}$ & Blood Effector CD8+ T cell \\
\hline $\mathrm{CM}_{\mathrm{B}, 8}$ & 0 & Cell $/ \mathrm{mm}^{3}$ & Blood Central Memory CD8+ T cell \\
\hline $\mathrm{EM}_{\mathrm{B}, 8}$ & 0 & Cell $/ \mathrm{mm}^{3}$ & Blood Effector Memory CD8+ T cell \\
\hline $\mathrm{N}_{\mathrm{Ln}, \mathrm{nc} 4}$ & $\mathrm{~N}_{\mathrm{B}, \mathrm{nc} 4} \times(\alpha /$ host_Ln $)$ & Cell count & Non-Mtb-specific LN Naïve CD4+ T cell \\
\hline $\mathrm{CM}_{\text {Ln,nc4 }}$ & $\mathrm{CM}_{\mathrm{B}, \mathrm{nc} 4} \times(\alpha /$ host_Ln $)$ & Cell count & Non-Mtb-specific LN Central Memory CD4+ T cell \\
\hline $\mathrm{N}_{\mathrm{B}, \mathrm{nc} 4}$ & {$[255,610] \times(1-\lambda)$} & Cell $/ \mathrm{mm}^{3}$ & Non-Mtb-specific Blood Naïve CD4+ T cell \\
\hline $\mathrm{E}_{\mathrm{B}, \mathrm{nc} 4}$ & {$[47,254] \times(1-\lambda)$} & Cell $/ \mathrm{mm}^{3}$ & Non-Mtb-specific Blood Effector CD4+ T cell \\
\hline $\mathrm{CM}_{\mathrm{B}, \mathrm{nc} 4}$ & {$[83,300] \times(1-\lambda)$} & Cell $/ \mathrm{mm}^{3}$ & Non-Mtb-specific Blood Central Memory CD4+ T cell \\
\hline $\mathrm{EM}_{\mathrm{B}, \mathrm{nc} 4}$ & {$[50,255] \times(1-\lambda)$} & Cell $/ \mathrm{mm}^{3}$ & Non-Mtb-specific Blood Effector Memory CD4+ T cell \\
\hline
\end{tabular}


Table 1. Cont.

\begin{tabular}{cccc}
\hline Variable & Value & Units & Description \\
\hline $\mathrm{N}_{\mathrm{Ln}, \mathrm{nc} 8}$ & $\mathrm{~B}_{\mathrm{N}, \mathrm{nc} 8} \times(\alpha /$ host_Ln $)$ & Cell count & Non-Mtb-specific LN Naïve CD8+ T cell \\
$\mathrm{CM}_{\mathrm{Ln}, \mathrm{nc} 8}$ & $\mathrm{CM}_{\mathrm{N}, \mathrm{nc} 8} \times(\alpha /$ host_Ln $)$ & Cell count & Non-Mtb-specific LN Central Memory CD8+ T cell \\
$\mathrm{N}_{\mathrm{B}, \mathrm{nc} 8}$ & {$[100,672] \times(1-\lambda)$} & Cell $/ \mathrm{mm}^{3}$ & Non-Mtb-specific Blood Naïve CD8+ T cell \\
$\mathrm{E}_{\mathrm{B}, \mathrm{nc} 8}$ & {$[43,317] \times(1-\lambda)$} & Cell $/ \mathrm{mm}^{3}$ & Non-Mtb-specific Blood Effector CD8+ T cell \\
$\mathrm{CM}_{\mathrm{B}, \mathrm{nc} 8}$ & {$[36,262] \times(1-\lambda)$} & Cell $/ \mathrm{mm}^{3}$ & Non-Mtb-specific Blood Central Memory CD8+ T cell \\
$\mathrm{EM}_{\mathrm{B}, \mathrm{nc} 8}$ & {$[11,156] \times(1-\lambda)$} & Cell $/ \mathrm{mm}^{3}$ & Non-Mtb-specific Blood Effector Memory CD8+ T cell \\
\hline
\end{tabular}

We examined the following 16 time points (shown as days post infection) during infection progression, chosen to match the time points of the NHP blood data samples, namely 1, 10, 20, 30, 42, $50,56,60,70,84,90,100,111,140,167$ and 200 days. A list of outputs analyzed with the correspondent sensitivity coefficients is shown in Tables 3-5, as well as in Figures 5-7.

\subsection{Experimental Data: Non Human Primate Lung and Blood Data}

For the purpose of model calibration both in the lung and blood compartments, we used the dataset described in our recent work [19]. Briefly, for the blood compartment, a total of 58 cynomolgus macaques (Macacca fasicularis) or non-human primates (NHPs) were previously infected with a low dose of Mtb (Erdman strain, 25-50 CFU). Blood samples were taken from 28 NHPs at the following time-points: pre Mtb infection and at days 10, 20, 30, 42, 56, 90 (or M3, 3 months), 120 (or M4), 150 (or M5) and 180 (or M6) post infection. Levels of T cells were measured, and stratified by CD4+ and CD8+ memory sub-populations based on the surface markers on the cells (expression of CD45RA and CD27, namely Naïve-N [CD45RA+ CD27+], Central Memory-CM [CD45RA- CD27+], Effector Memory-EM [CD45RA - CD27-] and Terminally Differentiated-TD or Effector-E [CD45RA+ CD27-]). For experimental data in the lung, numbers of granulomas and numbers of bacteria (referred to as colony forming units, or CFUs) per granuloma were collected at necropsy from 43 NHPs. See Supplementary Files 2 and 3.

\section{Results}

The results will be presented in two main parts. First we show how the updated model was calibrated to the experimental data to ensure the model is appropriate for study. In the second part we use uncertainty and sensitivity analysis methodologies applied to the comprehensive model to investigate and predict mechanisms that drive infection and other outcomes during the interplay between Mtb and the host.

\subsection{Model Calibration-Lung and Blood Compartments}

Our granuloma models were developed, calibrated and validated using extensive data primarily from NHPs and humans, and where lacking, from mice [21,24,25,34,36,38,39,41,63,64]. We calibrated the current model to NHP experimental data in the lung (i.e., bacteria known as colony forming units, or CFU per granuloma) and blood (memory $\mathrm{T}$ cell levels). Tables 1 and 2 show the ranges used to generate our in silico dataset of 3000 model simulations of CFU dynamics in the lung as well as T cell dynamics in the blood. Figure 3a shows our model calibration to experimental data on the number of bacteria (given as CFU, or colony-forming-units) per granuloma from the lungs of NHPs [32,38,42]. GranSim also provides the ability to not only track temporal dynamics of cells and molecules but also their spatial distribution, which can be validated directly by experimental data that are also provided from NHP granulomas. This allows for comprehensive spatial and temporal investigation of mechanisms driving the heterogeneity and variability that is observed in granuloma types and their corresponding outcomes (see Figure $3 \mathrm{~b}$ for examples of multiple in silico granuloma snapshots taken from the 3000 simulations and Figure 3 from [36] for examples of a comparison between a lung granuloma from an NHP with one generated from GranSim). 
(a)

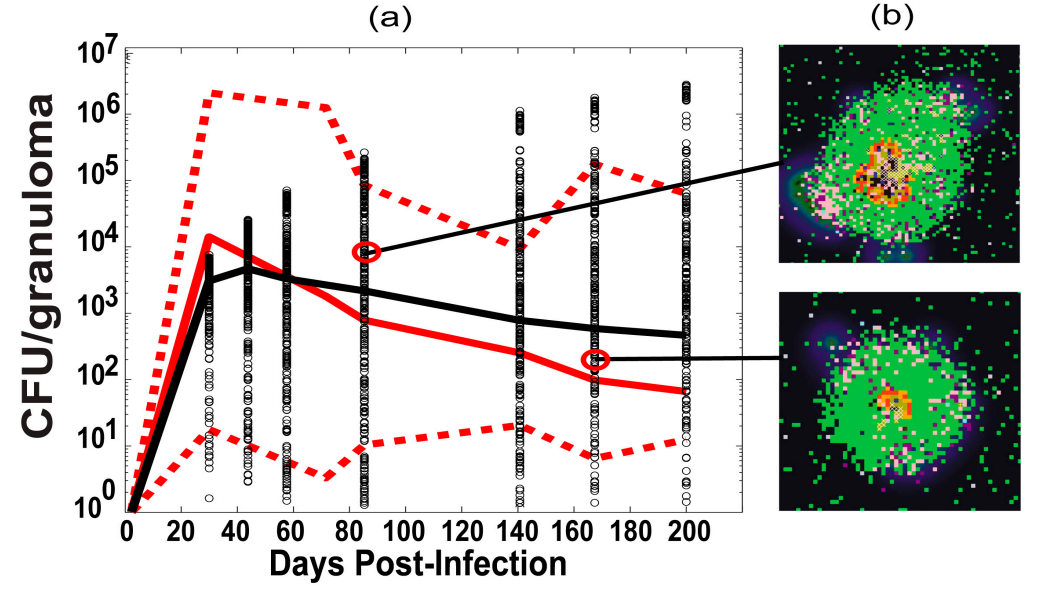

Figure 3. Computational model calibration: LUNG. (a) Time courses of CFU per granuloma. In red are shown NHP experimental data (median, max and min) for colony-forming-units (CFU)/granuloma (see details in the Supplementary File 2. They are plotted here versus our in silico datasets (black) of $\mathrm{CFU} /$ granuloma (lung compartment) from our computer simulations of 3000 granulomas coupled to the blood and LN dynamics). The $x$-axis shows a time span of infection up to 200 days to match the NHP blood data. The $y$-axis represents bacteria levels as CFU/granuloma. The in silico dataset of time courses of CFU/granuloma generated in the lung compartment (black circles, with the black solid line representing the median trajectory) are plotted together with experimental data on NHP $\mathrm{CFU} /$ granuloma (with the solid red line representing the median, and the dotted red lines representing the min and max values in the NHP data). The median trajectories for both the NHP and in silico data are calculated including the granulomas that cleared infection $(\mathrm{Mtb}<1)$, while the min trajectories excluded them; (b) Two snapshots of in silico granuloma corresponding to the points in the time courses of panel (a).

The current computational model was also calibrated with respect to blood T cell dynamics as measured in [36] (see Figure 4). Blood NHP experimental data are compared to median, 5th and 95th percentiles of our 3000 model simulations in the blood/LN compartments. Due to the limited and extremely variable NHP dataset that was available from the blood compartment, minimum and maximum ranges at each time point were chosen across all the subjects in order to establish the boundaries of our model simulations. Both the interpretation and accuracy of the measures of these different memory phenotypes in vitro are still being assessed (see [36] for a complete discussion of the uncertainty and variability associated with the NHP blood data and the current state-of-the-art in terms of cell profiling and Mtb-specificity). Currently the variability associated with each blood measure is not quantifiable experimentally (experiments by our collaborators are in progress in order to give us a better understanding of the experimental pure error for each blood assay). Thus, our major goal in calibrating blood dynamics was to ensure that our in silico simulations fell reasonably within the general behavior of the data (e.g., medians), rather than reproducing its large variability (e.g., $\mathrm{min} / \mathrm{max}$ ). Figure 4 illustrates how the model recapitulates the experimental data of host cell classes. Specifically, the predictions for the median trajectories of the Central Memory phenotypes are only affected for the maximum ranges. This can be explained by our uncertainty analysis assumptions. We assumed, a priori, uniform probability density functions for all the parameters and initial conditions that we varied (see Uncertainty Analysis section), thus we were forced to use conservative ranges for the Central Memory initial conditions in order to place the model median initial condition close to the median of the experimental data. 

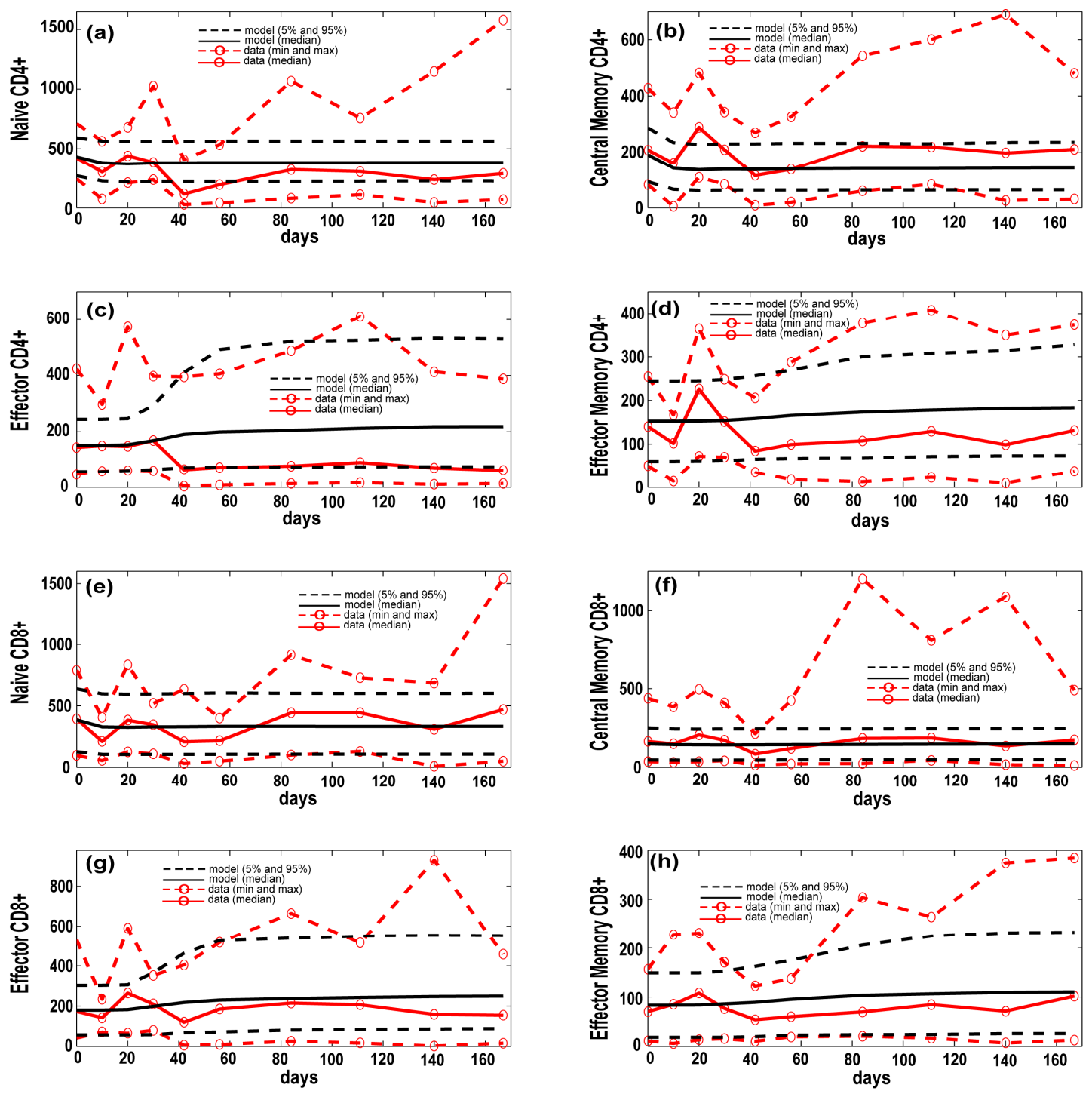

Figure 4. Computational model calibration (blood compartment). NHP experimental data on blood T cell phenotypes (see Supplementary File 3) are plotted here versus the in silico datasets of blood T cell phenotypes (blood compartment), from our computer simulations of 3000 granulomas coupled to the blood and LN dynamics. The $x$-axis shows a time span of infection up to 200 days to match the NHP blood data. The $y$-axis represents cells $/ \mathrm{cm}^{3}$. (a-h) In silico dataset of 3000 time courses of $8 \mathrm{~T}$ cell classes generated in the blood compartment (black solid line [mean] and black dashed lines [5th and 95th percentiles]) compared to experimental data on T cell phenotypes in the blood of Mtb-infected NHPs (red dashed lines with red open circles, representing the min and max). For the minimum and maximum of the NHP data we chose the lowest and highest values at any time point across all the NHPs. In silico predictions are displayed as median (black solid line) and minimum and maximum (dashed black lines). We show Naïve CD4+ T cells (a) and CD8+ T cells (e); Central Memory CD4+ T cells (b) and CD8+ T cells (f); Effector CD4+ T cells (c) and CD8+ T cells (g) and Effector Memory CD4+ T cells (d) and CD8+ T cells (h). The in silico data have been obtained by summing the respective $\mathrm{Mtb}$-specific and non Mtb-specific equations of the blood compartment of the computational model [36].

\subsection{Bacterial, CD4 and CD8 Proliferation Impact Infection Burden at the Granuloma Site}

After the model was adequately calibrated to the experimental data, we used it to ask questions about mechanisms playing key roles in immune protection, controlled inflammation, and in general 
adaptive immune response magnitude and timing during infection. Inflammation is associated with an immune response that is mounted in response to an infection. Typically, once infection is reduced and cleared, inflammation subsides. To adequately investigate mechanisms driving infection and inflammation, we perform uncertainty and sensitivity analysis (US/A) on many outcomes of the model (see Appendix B) at different times during the simulations, from the early onset (first 2 months), up to 200 days post infection. The results for the main mechanisms driving infection (e.g., total bacterial burden, or infected cells) are shown in Table 2.

Table 2. Significant Partial Rank Correlation Coefficients (PRCCs) for inflammation outcomes. List of all the parameters/mechanisms (rows) that have a significant (i.e., $p<10^{-3}$ ) PRCC with respect to outputs of the model that are directly related to some markers of infection (columns). See Appendix B for a detailed description of the outcomes analyzed here. $\mathrm{A}+($ or - ) indicates a positive (or negative) correlation between the parameter and the infection level outcome. The magnitude/strength of the correlation is given by the number of + (or - ). The table recapitulates, whenever possible, the dynamics over time. The outputs with * are selected as examples to illustrate PRCC time courses (see Figure 5). Ext Mtb means extracellular bacteria that is not inside DCs or macrophages, Tot Mtb means total bacteria intracellular and extracellular, Gran size means actual measure of the granuloma diameter. The parameters $\tau$ define thresholds for $\mathrm{T}$ cell recruitment at each vascular source (in terms of number of molecules). The parameter $\lambda$ represents the frequency of Mtb-specific Naïve T cells in the blood/LN (see Appendix A for details on all the parameters listed below).

\begin{tabular}{|c|c|c|c|c|c|}
\hline \multirow[b]{2}{*}{ Parameters } & \multicolumn{5}{|c|}{ INFECTION (LUNG) } \\
\hline & Tot Mtb * & Ext Mtb & Total Infected Macs * & Total Infected DCs * & Gran Size * \\
\hline growthRateIntMtb & +++ & +++ & +++ & +1 & \\
\hline lungExitInterval & & & & +++ & \\
\hline $\begin{array}{l}\tau_{\mathrm{T} \gamma-\mathrm{CC}}-\text { chemokine threshold } \\
\text { for } \mathrm{T} \gamma \text { recruitment }\end{array}$ & & & ++ & & \\
\hline \multicolumn{6}{|l|}{$\begin{array}{c}\tau_{\text {Treg-TNF }} \text {-tumor necrosis factor (TNF) } \\
\text { threshold for Treg recruitment }\end{array}$} \\
\hline $\mathrm{k}_{4}-\mathrm{CD} 4+\mathrm{T}$ precursorproliferation & --- & --- & & -- & \\
\hline $\mathrm{k}_{13}-\mathrm{CD} 8+\mathrm{T}$ precursorproliferation & --- & --- & --- & --- & $\begin{array}{c}\text { early }+ \text { then } \\
---\end{array}$ \\
\hline \multicolumn{6}{|l|}{$\begin{array}{l}\text { scalingMDC-Scaling to host } \\
\text { factor representing the number of } \\
\text { granulomas developing in the } \\
\text { whole lung at time of infection }\end{array}$} \\
\hline $\mathrm{k}_{11}$-Naïve CD8+ T priming & -- & -- & -- & -- & -- \\
\hline$\%$ of Resident DCs & & & & ++ & - \\
\hline$\lambda$ & & -- & & & \\
\hline
\end{tabular}

US/A results support a key role for $\mathrm{T}$ cell priming and proliferation (in the lymph node) in mounting a protective immune response to $\mathrm{Mtb}$ infection. In particular, by increasing $\mathrm{CD} 8+\mathrm{T}$ cell proliferation we can impact a large spectrum of host and pathogen immunological events, from total levels of infection (e.g., bacterial numbers in the lungs, total infected cells, ...) and inflammation, to granuloma size and how much central caseation is present in granulomas. Table 2 highlights mechanisms/parameters that we found to be significantly associated with changes in infection correlates, such as total numbers of infected macrophages or numbers of dendritic cells, total bacteria numbers and granuloma size. Not surprisingly (as a positive control), higher bacterial numbers and numbers of infected macrophages emerge from increasing bacterial growth rates (intracellular). Increasing rates of CD4+ and CD8+ T cell proliferation, as well as rates of CD8+ T cell priming in LN have a positive impact on total bacteria in lung (lower levels). The latter three mechanisms exemplify the concept of inter-compartmental/inter-scale effects, where mechanisms operating in one compartment/organ (LN in our case) are affecting outcomes in a different compartment/organ 
(lung in our case). On the other hand, the significant effect of bacterial growth rate on outcomes clearly illustrates an intra-compartmental/intra-scale effect.

Figure 5 shows time courses of the sensitivity indexes (i.e., PRCCs) for some of the outputs in Table 2. A vertical dotted line on the plots represents the early events (i.e., first 2 months post infection). Some mechanisms/parameters have a significant PRCC only early on during infection (e.g., intracellular bacterial growth rate in Figure 5a), while some elicit their regulatory effects only late during infection (e.g., CD8+ T cell priming $\left[k_{11}\right]$ in Figure $5 b$ ). Interestingly, the CD8+ T cell precursor proliferation rate $\left[k_{13}\right]$ changes their impact on the granuloma size over time (Figure $5 d$ ).
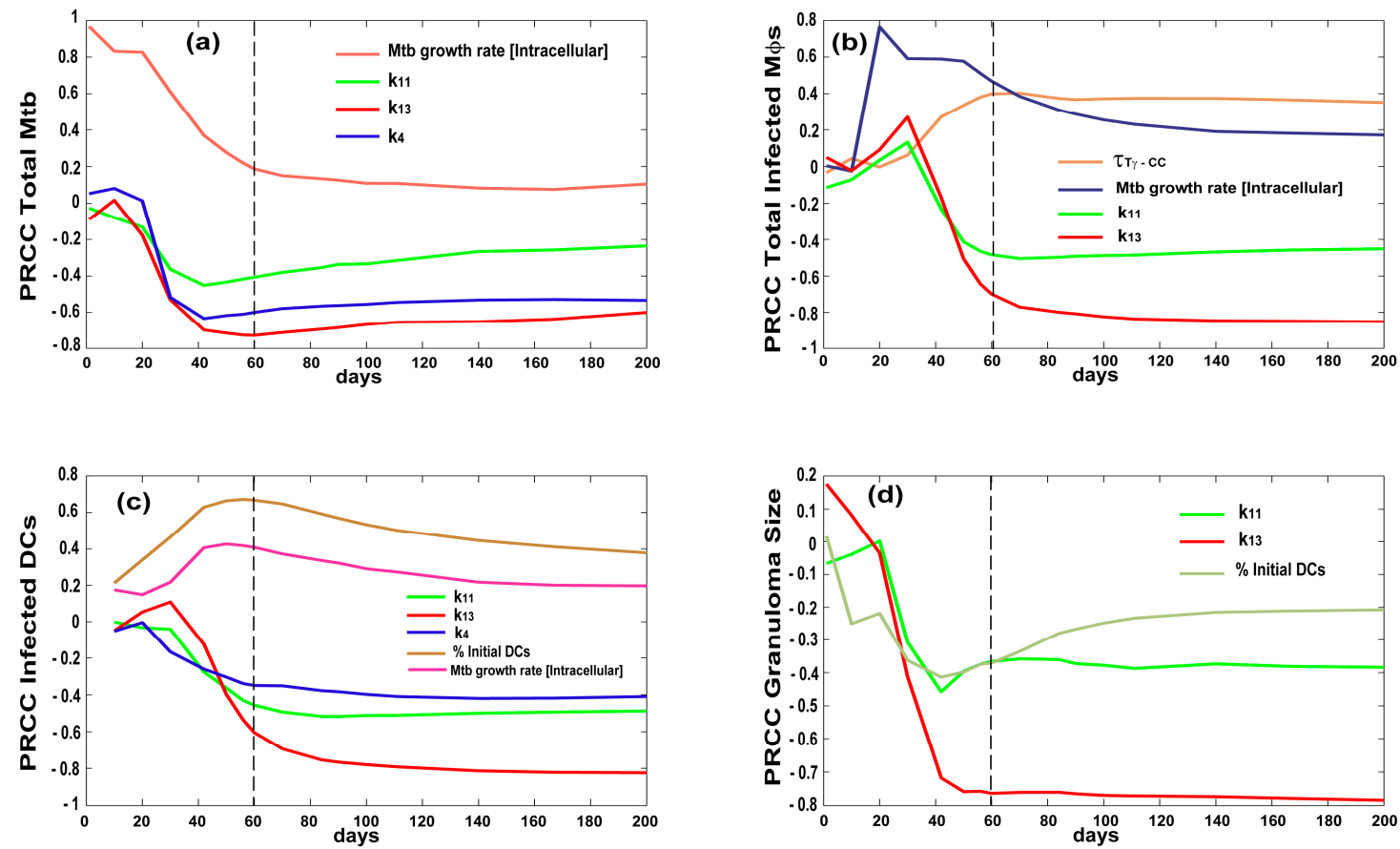

Figure 5. Time courses for Partial Ranked Correlation Coefficient (PRCC) of mechanisms / parameters affecting infection outcomes as they relate to Table 2. Each curve plotted is days post infection (up to 200 days) on the $x$-axis and PRCC values on the $y$-axis (that vary between -1 and 1 ). The PRCCs plotted are only ones that were significant (i.e., $p<10^{-3}$ ) and with an absolute value greater than 0.3. Outcomes shown are (a) total $\mathrm{Mtb}$, (b) total infected macrophages, (c) total infected dendritic cells and (d) granuloma size. Compare with Table 2 results. Parameter definitions: $\mathrm{k}_{4}$ [CD4+ T cell precursor proliferation in the $\mathrm{LN}$ ], $\mathrm{k}_{13}$ [CD8+ $\mathrm{T}$ cell precursor proliferation in the $\mathrm{LN}$ ], $\tau_{\mathrm{T} \gamma}-\mathrm{CC}$ : chemokine threshold for $\mathrm{T} \gamma$ cells recruitment to the lung, $\tau_{\text {Treg-TNF}}$ : TNF threshold for Treg cells recruitment to the lung, $\mathrm{k}_{11}$ : Naïve CD8 priming (see Appendix A for details on the parameters).

\subsection{Priming and Proliferation in the LN Drives Inflammation at the Site of Infection}

Inflammation is when many immune cells and molecules are recruited and secreted at a site of infection. This is a double-edged sword in most infections where the influx of mediators is helpful to control infection; however, too much inflammation can cause damage to the host and so must be tightly regulated. Here, we have many ways to represent inflammation in the model. Table 3 and Figure 6 showcase different outputs that we track over time that are associated with pro- and anti-inflammatory events at the site of infection of the lung. Table 3 shows sensitivities associated to total macrophage activation, total Pet Hot (a proxy for metabolically active sites as measured through PET CT scan, see Figure 2 legend herein and for details [53,65]), tissue damage (caseation/necrosis), a pro-inflammatory molecule (Tumor Necrosis Factor-TNF) and an anti-inflammatory molecule (Interleukin 10-IL-10). Typically it is thought that inflammation in tuberculosis, and most diseases, 
is associated with infection. However Table 3 shows only a marginal direct effect of bacterial growth rate on inflammation. This suggests the host is mediating most of the inflammation observed.
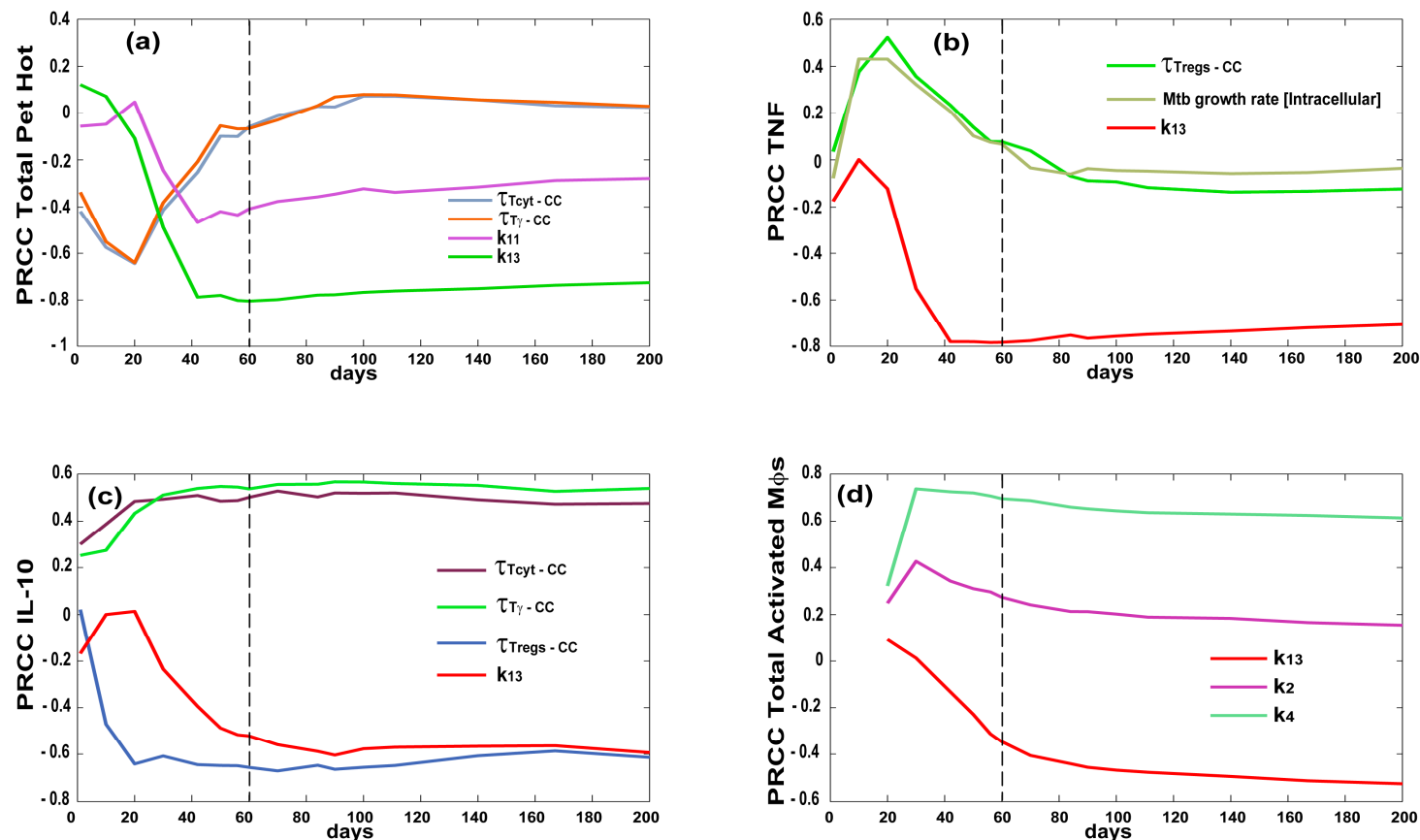

Figure 6. Partial Ranked Correlation Coefficient (PRCC) time courses of mechanisms/parameters affecting inflammation outcomes. Each plot has days post infection (up to 200 days) on the $x$-axis and PRCC values on the $y$-axis (between -1 and 1). The PRCCs plotted are the only ones that resulted significant (i.e., $p<10^{-3}$ ) and with an absolute value greater than 0.3. Outcomes shown are (a) total Pet Hot, (b) TNF, (c) IL-10 and (d) total activated macrophages. Parameter definitions: $\tau_{\mathrm{T} \gamma}-\mathrm{CC}$ - chemokine threshold for $\mathrm{T} \gamma$ recruitment, $\tau_{\mathrm{Tcyt}}-\mathrm{CC}$ - chemokine threshold for Tcyt recruitment, $\tau_{\text {Treg-CC }}$ - chemokine threshold for Treg recruitment, $\mathrm{k}_{2}-$ Naïve CD4+ T cell priming, $\mathrm{k}_{4}-\mathrm{CD} 4+\mathrm{T}$ cell precursor proliferation, $\mathrm{k}_{13}-\mathrm{CD} 8+\mathrm{T}$ cell precursor proliferation, $\mathrm{k}_{14}-\mathrm{CD} 8+\mathrm{T}$ cell differentiation to effector, $\mathrm{k}_{11}$-Naïve CD8+ T cell priming (see Appendix A for details on the parameters).

Table 3. Significant PRCCs for inflammation outcomes. List of all the parameters/mechanisms (rows) that have a significant (i.e., $p<10^{-3}$ ) PRCC with respect to outputs of the model that are directly related to inflammation (columns). See Appendix B for a detailed description of the outcomes analyzed here. $\mathrm{A}+(\mathrm{or}-$ ) indicates a positive (or negative) correlation between the parameter and the outcome. The magnitude/strength of the correlation is given by the number of $+($ or -$)$. The table recapitulates, whenever possible, the dynamics over time. The outputs with * are selected as examples to illustrate PRCC time courses (see Figure 6). See Appendix A for details on the parameters listed below.

\begin{tabular}{|c|c|c|c|c|c|}
\hline \multirow[b]{2}{*}{ PARAMETERS } & \multicolumn{5}{|c|}{ INFLAMMATION (LUNG) } \\
\hline & $\begin{array}{l}\text { Total Activated } \\
\text { Macrophages }\end{array}$ & Tot Pet Hot * & $\begin{array}{l}\text { Caseation/ } \\
\text { Necrosis }\end{array}$ & TNF * & IL10 * \\
\hline growthRateIntMtb & & + early $^{1}$ & & ++ early & \\
\hline $\begin{array}{c}\tau_{\mathrm{T} \gamma}-\mathrm{CC}-\text { chemokine } \\
\text { threshold for } \mathrm{T} \gamma \text { recruitment }\end{array}$ & & - - early & & - early $^{1}$ & +++ \\
\hline $\begin{array}{l}\tau_{\text {Tcyt-CC }}-\text { chemokine } \\
\text { threshold for Tcyt recruitment }\end{array}$ & & - - early & & $-\underset{1}{- \text { early then }+}$ & +++ \\
\hline $\begin{array}{c}\tau_{\text {Treg-CC}}-\text { chemokine } \\
\text { threshold for Treg recruitment }\end{array}$ & $-{ }^{1}$ & + and then ${ }^{1}$ & & ++ early & --- \\
\hline $\mathrm{k}_{2}$-Naïve CD4 priming & ++ & & & - early ${ }^{1}$ & +1 \\
\hline $\begin{array}{c}\mathrm{k}_{4}-\mathrm{CD} 4+\mathrm{T} \\
\text { precursor proliferation }\end{array}$ & +++ & & & & $+{ }^{1}$ \\
\hline
\end{tabular}


Table 3. Cont.

\begin{tabular}{|c|c|c|c|c|c|}
\hline \multirow[b]{2}{*}{ PARAMETERS } & \multicolumn{5}{|c|}{ INFLAMMATION (LUNG) } \\
\hline & $\begin{array}{l}\text { Total Activated } \\
\text { Macrophages }\end{array}$ & Tot Pet Hot * & $\begin{array}{l}\text { Caseation/ } \\
\text { Necrosis }\end{array}$ & TNF * & IL10 * \\
\hline $\begin{array}{c}\mathrm{k}_{13}-\mathrm{CD} 8+\mathrm{T} \\
\text { precursor proliferation }\end{array}$ & --- & --- & $\begin{array}{c}+++ \text { early } \\
- \text { late }\end{array}$ & --- & --- \\
\hline $\begin{array}{c}\mathrm{k}_{14}-\mathrm{CD} 8+\mathrm{T} \\
\text { differentiation-effector }\end{array}$ & & $+{ }^{1}$ & & $+{ }^{1}$ & \\
\hline $\mathrm{k}_{11}$-Naïve CD8 priming & & - & $\begin{array}{l}++ \text { early } \\
\text { - late }\end{array}$ & -1 & -1 \\
\hline
\end{tabular}

${ }^{1}$ These PRCCs are below 0.3, so they are not shown in Figure 6.

While higher CD4+ $\mathrm{T}$ cell proliferation rates (i.e., $\mathrm{k}_{4}$ ) in the $\mathrm{LN}$ compartment are naturally associated with higher levels of macrophage activation (i.e., a necessary step in macrophage activation), higher CD8+ $\mathrm{T}$ cell proliferation rates (i.e., $\mathrm{k}_{13}$ ) have a general anti-inflammatory role, likely due to the higher levels of killing of infected cells and lower levels of bacteria. However, the higher cytotoxicity, likely associated with higher CD8+ T cell proliferation rates, results in greater tissue damage, as shown by the strong positive correlation between $\mathrm{k}_{13}$ and higher levels of central caseation/necrosis within granulomas. It is interesting to note how the levels of IL-10 (a typically anti-inflammatory molecule) are strongly affected by the different effector $\mathrm{T}$ cell chemokine thresholds for recruitment at the site of infection as compared to TNF, which is more of a pro-inflammatory molecule. Figure 6 shows a more comprehensive picture of the impact of many of these mechanisms on inflammation dynamics during infection, emphasizing the timing aspect as well: some are important early (e.g., chemokine threshold for recruitment, Figure $6 a, b$ ) versus later in infection progression (e.g., $k_{13}$ in Figure $6 b-d$ ).

\subsection{T Cell Priming, Proliferation and Trafficking Determine the Timing and Magnitude of the Immune Response at the Site of Infection and in the Blood}

A protective immune response is one where not only is the bacteria cleared or strongly contained, but where damage to the host, induced by too much inflammation, is controlled. Using our US/A, we characterized key mechanisms driving a protective immune response at the site of infection by tracking Mtb-specific T cells as well as dendritic cell dynamics in the lung (see Table 4). CD8+ T cell proliferation $\left(\mathrm{k}_{13}\right)$ shows up again with very strong correlations across all outcomes. It is interesting to note how $\mathrm{T}_{\gamma}$ and $\mathrm{T}_{\text {cyt }}$ seem to be complementary: high CD8+ $\mathrm{T}$ cell proliferation rates mirror lower levels of $\mathrm{T}_{\gamma}$ cells at the site of infection. Regulatory $\mathrm{T}$ cells $\left(\mathrm{T}_{\text {regs }}\right)$ are represented as a fraction of $\mathrm{T}_{\gamma}$ in the model (for the details of the ODE system describing lymph node and blood dynamics, see Supplementary File 1), thus both outcomes are affected by the same mechanism (e.g., $\mathrm{k}_{4}-\mathrm{CD} 4$ precursor proliferation). Tables 3 and 5 emphasize a key protective role for both cytotoxic T-cell and $\mathrm{T}_{\gamma}$-cell responses in the lung (Figure $7 \mathrm{a}, \mathrm{b}$ ). However, these results suggest a more comprehensive role for $\mathrm{CD} 8+\mathrm{T}$ cell priming and proliferation in regulating not only adaptive immune response magnitude in the blood and at the site of infection, but also on DC stimulation/maturation and trafficking. Mechanisms impacting blood outcomes are shown in Table 5 and Figure 7c,d. Here we see how most of the mechanisms elicit their effect early during infection (first 2 months post infection, as shown by the dotted vertical line in Figures 5-7), suggesting that the events happening right after the onset of the infection can shape a more protective response in the long term (which is ideal in a chronic infection such as tuberculosis).

Delaying trafficking of DCs to lymphatics and ultimately to the LN has a negative impact on all the memory $\mathrm{T}$ cell phenotypes in the blood (see lungExitInterval and lymphExitInterval mechanisms in Table 5 and Figure 7c,d). Again, this impact is important early during infection. Higher levels of resident DCs in the lung before infection are also important in establishing a more protective role for effector and effector memory $\mathrm{T}$ cell phenotypes in the blood (see Figure 7c,d). This latter result 
stresses again how early events are critical to establishing an effective and timely response during Mtb infection.

Table 4. Significant PRCCs for lung adaptive immune response outcomes. List of all the parameters / mechanisms (rows) that have a significant (i.e., $p<10^{-3}$ ) PRCC with respect to outputs of the model that are directly related to the adaptive immune response elicited in the lung, the site of infection (columns). See Appendix B for a detailed description of the outcomes analyzed here. $\mathrm{A}+($ or - ) indicates a positive (or negative) correlation between the parameter and the outcome. The magnitude/strength of the correlation is given by the number of $+($ or - ). The table recapitulates, whenever possible, the dynamics over time. The outputs with * are selected as examples to illustrate PRCC time courses (see Figure 7a,b). See Appendix A for details on the parameters listed below.

\begin{tabular}{|c|c|c|c|c|c|c|c|}
\hline \multirow[b]{2}{*}{ PARAMETERS } & \multicolumn{7}{|c|}{ ADAPTIVE IMMUNE RESPONSE (LUNG) } \\
\hline & $\begin{array}{c}\text { Mtb-Specific Tgam } \\
\text { (Pro-Inflammatory) } \\
\text { T Cells * }\end{array}$ & $\begin{array}{c}\text { Mtb-Specific Tcyt } \\
* \text { (Cytotoxic) } \\
\text { T Cells }\end{array}$ & $\begin{array}{c}\text { Recruited } \\
\text { Mtb-Specific } \\
\text { Treg } \\
\end{array}$ & $\begin{array}{c}\text { Recruited } \\
\text { Mtb-Specific } \\
\text { Tcyt }\end{array}$ & $\begin{array}{c}\text { DC } \\
\text { Stimulated }\end{array}$ & $\begin{array}{c}\text { DC } \\
\text { Exited } \\
\text { Lung } \\
\end{array}$ & $\begin{array}{c}\text { DC } \\
\text { Exited } \\
\text { Lymph }\end{array}$ \\
\hline $\begin{array}{c}\lambda \text {-Frequency of } \\
\text { Mtb-specific Naïve T } \\
\text { cells in the blood/LN }\end{array}$ & & + then $-{ }^{1}$ & & & & & \\
\hline $\begin{array}{c}\mathrm{k}_{4}-\mathrm{CD} 4 \\
\text { precursor proliferation }\end{array}$ & +++ & & ++ & & & & \\
\hline $\begin{array}{c}\mathrm{k}_{13}-\mathrm{CD} 8 \\
\text { precursor proliferation }\end{array}$ & -- & +++ & --- & ++ & --- & --- & --- \\
\hline $\mathrm{k}_{2}-\mathrm{CD} 4$ priming & +++ early & & & & & & \\
\hline $\begin{array}{c}\tau_{\text {Treg-CC }} \text { - chemokine } \\
\text { threshold for } \\
\text { Treg recruitment }\end{array}$ & & $--^{1}$ & & & & & \\
\hline
\end{tabular}

${ }^{1}$ These PRCCs are below 0.3, so they are not shown in Figure 7.

Table 5. Significant PRCCs for blood adaptive immune response outcomes. List of all the parameters / mechanisms (rows) that have a significant (i.e., $p<10^{-3}$ ) PRCC with respect to outputs of the model that are directly related to Mtb-specific Memory $\mathrm{T}$ cell phenotypes in the blood compartment (columns). $\mathrm{A}+($ or - ) indicates a positive (or negative) correlation between the parameter and the outcome. The magnitude/strength of the correlation is given by the number of $+($ or - ). The table recapitulates, whenever possible, the dynamics over time. The outputs with * are selected as examples to illustrate PRCC time courses (see Figure $7 \mathrm{c}, \mathrm{d}$ ). See Appendix A for details for the parameters listed below.

\begin{tabular}{|c|c|c|c|c|c|c|c|c|}
\hline \multirow[b]{2}{*}{ PARAMETERS } & \multicolumn{8}{|c|}{ BLOOD OUTCOMES-Mtb-Specific T Cells } \\
\hline & $\begin{array}{l}\text { Naïve } \\
\text { CD4 }\end{array}$ & $\begin{array}{l}\text { Effector } \\
\text { CD4* }\end{array}$ & $\begin{array}{l}\text { Central } \\
\text { Memory } \\
\text { CD4 }\end{array}$ & $\begin{array}{l}\text { Effector } \\
\text { Memory } \\
\text { CD4 }\end{array}$ & $\begin{array}{l}\text { Naïve } \\
\text { CD8 }\end{array}$ & $\begin{array}{l}\text { Effector } \\
\text { CD8* }\end{array}$ & $\begin{array}{l}\text { Central } \\
\text { Memory } \\
\text { CD8 }\end{array}$ & $\begin{array}{l}\text { Effector } \\
\text { Memory } \\
\text { CD8 }\end{array}$ \\
\hline lungExitInterval & & --- early & --- early & --- early & & --- early & --- early & --- early \\
\hline lymph_ExitInterval & & --- early & --- early & --- early & & --- early & --- early & --- early \\
\hline$\%$ of Resident DCs & & ++ early & & ++ early & & +++ early & & +++ early \\
\hline $\begin{array}{l}\text { Initial Conditions for Mtb-specific } \\
\text { Naïve CD4+ T cells-BLOOD }\end{array}$ & +++ & & & & & & & \\
\hline $\begin{array}{l}\text { Initial Conditions for Mtb-specific } \\
\text { Naïve CD8+ T cells-BLOOD }\end{array}$ & & & & & +++ & & ++ early & \\
\hline $\begin{array}{l}\text { host_LN_Number of involved } \\
\text { lymph nodes in the host }\end{array}$ & & & -- & & & & ++ early & \\
\hline $\begin{array}{l}\lambda \text {-Frequency of Mtb-specific } \\
\text { Naïve T cells in the blood/LN }\end{array}$ & +++ & +++ early & ++ early & ++ early & +++ & +++ early & +++ early & +++ early \\
\hline $\mathrm{k}_{1}$-Naïve CD4 recruitment rate & --- & +++ early & ++ early & +++ early & & & & \\
\hline $\mathrm{k}_{10}$-Naïve CD8 recruitment rate & & & & & --- & +++ early & +++ early & +++ early \\
\hline
\end{tabular}


Table 5. Cont.

\begin{tabular}{|c|c|c|c|c|c|c|c|c|}
\hline \multirow[b]{2}{*}{ PARAMETERS } & \multicolumn{8}{|c|}{ BLOOD OUTCOMES-Mtb-Specific T Cells } \\
\hline & $\begin{array}{l}\text { Naïve } \\
\text { CD4 }\end{array}$ & $\begin{array}{l}\text { Effector } \\
\text { CD4* }\end{array}$ & $\begin{array}{l}\text { Central } \\
\text { Memory } \\
\text { CD4 }\end{array}$ & $\begin{array}{l}\text { Effector } \\
\text { Memory } \\
\text { CD4 }\end{array}$ & $\begin{array}{l}\text { Naïve } \\
\text { CD8 }\end{array}$ & $\begin{array}{l}\text { Effector } \\
\text { CD8* }\end{array}$ & $\begin{array}{l}\text { Central } \\
\text { Memory } \\
\text { CD8 }\end{array}$ & $\begin{array}{l}\text { Effector } \\
\text { Memory } \\
\text { CD8 }\end{array}$ \\
\hline $\mathrm{k}_{2}$-Naïve CD4 priming & --- & +++ early & ++ early & +++ early & & +++ early & +++ early & +++ early \\
\hline $\mathrm{k}_{11}$-Naïve CD8 priming & & & & & --- & +++ early & +++ early & +++ early \\
\hline $\mathrm{k}_{4}-\mathrm{CD} 4$ precursor proliferation & & +++ & +++ & +++ & & & & \\
\hline $\mathrm{k}_{13}-\mathrm{CD} 8$ precursor proliferation & & & & & & +++ & +++ & +++ \\
\hline $\begin{array}{l}\mathrm{k}_{5} \text {-Precursor CD4 differentiation } \\
\text { to Effector rate }\end{array}$ & & $+++/-/+$ & --- & $+++/-/+$ & & & & \\
\hline $\mathrm{k}_{14}-\mathrm{CD} 8$ differentiation to effector & & & & & & $+++/-/+$ & --- & +++ early \\
\hline$\mu_{5}$-Mature DC half-life in the LN & & & & & & -- early & & \\
\hline
\end{tabular}

\section{LUNG}
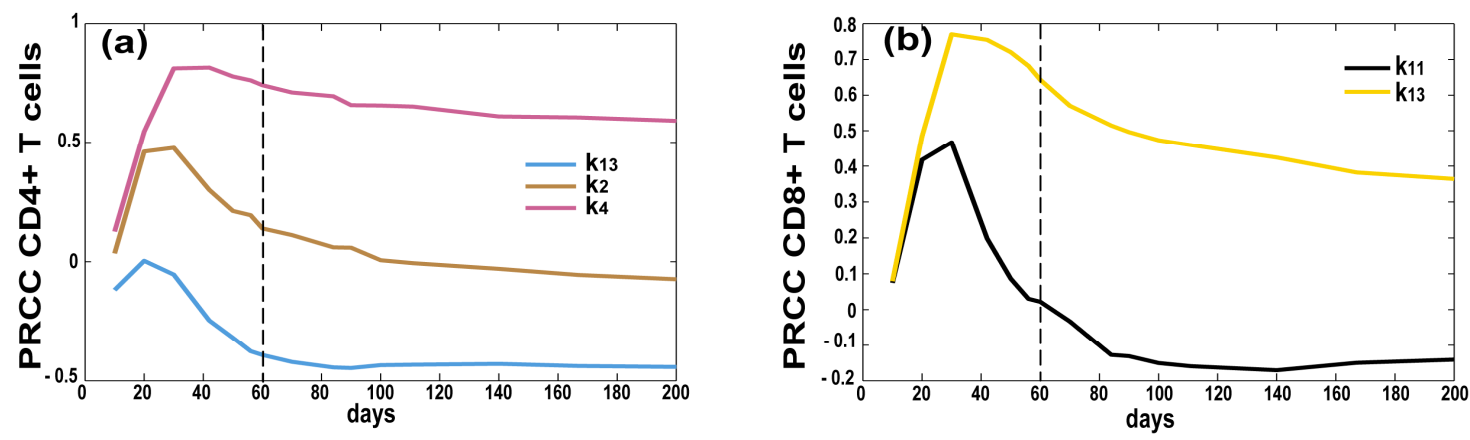

BLOOD
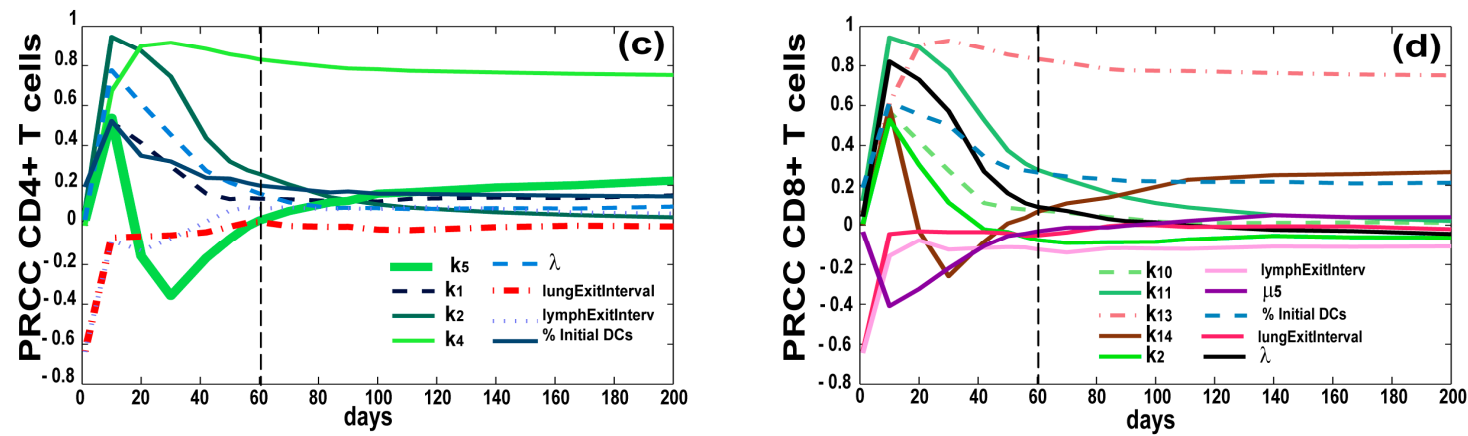

Figure 7. Partial Ranked Correlation Coefficient (PRCC) time courses of mechanisms/parameters affecting adaptive immune response in the lung and blood compartments. Each plot has days post infection (up to 200 days) on the $x$-axis and PRCC values on the $y$-axis (between -1 and 1 ). The PRCCs plotted are the only ones that resulted significant (i.e., $p<10^{-3}$ ) and with an absolute value greater than 0.3. Outcomes shown are Mtb-specific Effector T cells in the lung ((a) CD4+ T cells and (b) CD8+ T cells) and in the blood ((c) CD4+ T cells and (d) CD8+ T cells). Parameter definitions: $\mathrm{k}_{2}-$ Naïve CD4+ T cell priming, $\mathrm{k}_{4}-\mathrm{CD} 4+\mathrm{T}$ cell precursor proliferation, $\mathrm{k}_{13}-\mathrm{CD} 8+\mathrm{T}$ cell precursor proliferation, $\mathrm{k}_{14}-\mathrm{CD} 8+\mathrm{T}$ cell differentiation to effector, $\mathrm{k}_{11}-\mathrm{Naïve} \mathrm{CD} 8+\mathrm{T}$ cell priming, $\lambda$ : Frequency of Mtb-specific Naïve T cells in the blood/LN, $\mu_{5}$ : half-life of Mature DCs in the LN (see Appendix A for details on the parameters).

\section{Discussion}

A key step to mounting a protective immune response to $\mathrm{Mtb}$ and to most bacterial infection is represented by CD4+ and CD8+ T cell priming in lymph nodes. Facilitating migration of dendritic cells from the site of infection to the lymphatics, as well as enhancing trafficking of CD4+ and CD8+ effector $\mathrm{T}$ cells from the blood to the site of infection represent an important mechanism that could 
impact $\mathrm{TB}$ granuloma formation and function, and ultimately determine the outcome of $\mathrm{TB}$ infection in the host.

This study takes a multi-compartmental approach to studying antigen presentation, T cell priming, differentiation and trafficking in the context of TB granuloma formation. To better address these mechanisms, we built a new cell type, namely dendritic cell, into our existing multi-compartmental agent-based model of TB granuloma formation in the lung coupled to blood and lymph node dynamics [36]. This new model formulation allows us to better represent and investigate the impact of dendritic cell dynamics $[20,22]$ on important aspects of immunity: antigen presentation, $\mathrm{T}$ cell priming, memory $\mathrm{T}$ cell generation, and ultimately into TB infection progression.

We successfully calibrated the model with non-human primate (NHP) experimental data on granulomas and bacterial levels in the lung, as well as longitudinal measures of memory $\mathrm{T}$ cell levels in the blood. The model is also able to recapitulate typical spatial distribution of cells within NHP granulomas in the lung (see Figure 3 in [36]).

The main conclusion of this study is that early events after initial Mtb infection are critical to establishing a timely and effective response. Although IFN- $\gamma$, macrophage activation and CD4+ T cells are necessary for mounting a protective response to Mtb [66], our results highlight an equally relevant role for $\mathrm{CD} 8+\mathrm{T}$ cells, as suggested in previous experimental and modeling studies [67-69]. We show how we can lower bacterial burden and inflammation at the site of infection by enhancing either $\mathrm{CD} 4+$ or $\mathrm{CD} 8+\mathrm{T}$ cell proliferation in the lymph node early on during infection (i.e., within the first 2 months). In some cases CD4+ and CD8+ T cells complement each other to achieve protection. For example, high CD8+ T cell proliferation rates in the lymph node result in overall lower levels of effector CD4+ $\mathrm{T}$ cells at the granuloma site (i.e., $\mathrm{T} \gamma$ cells at the site of infection). In other words a larger cytotoxic $\mathrm{T}$ cell response (achieved by higher CD8+ $\mathrm{T}$ cell proliferation rates) can compensate for lower levels of $\mathrm{T} \gamma$ cells at the site of infection.

Overall, T cell proliferation in the LN and T cell trafficking to the lung determine both the timing and magnitude of adaptive response at the site of infection and in the blood. Thus, identifying drugs that would enhance these processes could assist in the treatment of infection, as has been suggested in tumors [70].

By introducing dendritic cells into the model, we are able to better control both timing and magnitude of the mechanisms driving the adaptive $\mathrm{T}$ cell responses. In fact, we can negatively impact memory $\mathrm{T}$ cell phenotypes (both CD4+ and CD8+) by simply delaying dendritic cell trafficking to the draining lymph node. However, this outcome can only be achieved in the early stages of infection. This conclusion reinforces the working hypothesis that the best protective response to Mtb infection has to be mounted very early; otherwise the best outcome that can be achieved is a controlled chronic infection.

In the current model formulation, we describe cellular dynamics in the lymph node and blood compartments with a sufficient level of detail by a temporal-only representation (i.e., ODE system). However, with the introduction of dendritic cells in the model as agents, we are now working on implementing different subsets of Mtb-specificity in an ABM formulation of LNs [40,71] that can be used to replicate current vaccine clinical trials [72], as well as to test innovative immunotherapy strategies already used in cancer $[73,74]$ but within the context of TB infection. It is this pairing of mathematical and computer modeling with experimental studies that has the greatest potential to push scientific discovery to the next level.

Supplementary Materials: The following are available online at http://www.mdpi.com/2079-3197/4/4/39/s1. Supplementary File 1: System of ordinary differential equations describing LN-blood dynamics of the computational model; Supplementary File 2: Lung data; Supplementary File 3: Blood data.

Acknowledgments: This research was supported by the following grants: R01 AI123093-01, R01 EB012579, R01 HL 110811. This research used also resources of the National Energy Research Scientific Computing Center, which is supported by the Office of Science of the U.S. Department of Energy under Contract No. DE-AC02-05CH11231 and the Extreme Science and Engineering Discovery Environment (XSEDE), which is supported by National Science 
Foundation grant number ACI-1053575. We thank Paul Wolberg for computational assistance and Joe Waliga for help with the Supplemental Website.

Author Contributions: Both authors conceived, designed, and performed the model building and simulations; both authors also analyzed the data and contributed analysis tools; both authors wrote the paper.

Conflicts of Interest: The authors declare no conflict of interest.

\section{Abbreviations}

The following abbreviations are used in this manuscript:

TB

Mtb Mycobacterium tuberculosis

LN lymph node

\section{Appendix A}

List of parameters and ranges for the computational model. Listed are the baseline parameter values used in the lymph node (LN), blood, and ordinary differential equation (ODE) compartments along with definitions and references to the values we chose. Those parameters marked with a * indicate they were calculated based upon the initial conditions of the system and the corresponding LN efflux term. These parameters were not varied during Latin hypercube sampling (LHS) experiments as they were constrained by a corresponding LN efflux parameter and the assumption that our initial conditions meet system homeostasis.

\begin{tabular}{|c|c|c|c|c|}
\hline Parameter & Value & Units & Description & Reference \\
\hline$\alpha$ & $5.6 \times 10^{5}$ & $\mu \mathrm{L}$ & $\begin{array}{l}\text { Conversion factor from Blood to Ln } \\
\text { (max. blood volume) }\end{array}$ & Estimated and [36] \\
\hline$\lambda$ & {$\left[10^{-5}, 10^{-3}\right]$} & “” & $\begin{array}{l}\text { Frequency of Mycobacterium } \\
\text { tuberculosis }(\mathrm{Mtb} \text { )-specific Naïve T } \\
\text { cells in the blood/LN }\end{array}$ & [75-77] \\
\hline scalingMDC & {$[5,15]$} & Count & $\begin{array}{l}\text { Scaling to host factor representing } \\
\text { the number of granulomas } \\
\text { developing in the whole lung at } \\
\text { time of infection }\end{array}$ & [52] \\
\hline $\operatorname{Sn} 4 *$ & $\mathrm{~N}_{\mathrm{LN}, 4} \times(\alpha /$ host_Ln $)$ & Cell $/ \mu L^{*}$ day & $\begin{array}{l}\text { Thymic output of Naïve } \\
\text { CD4+ T cells }\end{array}$ & $\begin{array}{c}\text { Estimated from } \\
\text { Uncertainty Analysis }\end{array}$ \\
\hline $\mathrm{hs}_{4}$ & 10 & Cell count & $\begin{array}{l}\text { Precursor CD4+ T cell proliferation } \\
\text { half saturation }\end{array}$ & $\begin{array}{c}\text { Estimated from } \\
\text { Uncertainty Analysis }\end{array}$ \\
\hline $\mathrm{hs}_{5}$ & 10 & Cell count & $\begin{array}{c}\text { Precursor CD4+ T cell } \\
\text { differentiation half saturation }\end{array}$ & $\begin{array}{c}\text { Estimated from } \\
\text { Uncertainty Analysis }\end{array}$ \\
\hline $\mathrm{hs}_{8}$ & 40 & Cell count & $\begin{array}{l}\text { Central Memory CD4+ T cell } \\
\text { recruitment half saturation }\end{array}$ & $\begin{array}{c}\text { Estimated from } \\
\text { Uncertainty Analysis }\end{array}$ \\
\hline $\mathrm{hs}_{10}$ & 25 & Cell count & $\begin{array}{c}\text { Naïve CD8+ T cell recruitment half } \\
\text { saturation }\end{array}$ & $\begin{array}{c}\text { Estimated from } \\
\text { Uncertainty Analysis }\end{array}$ \\
\hline $\mathrm{hs}_{11}$ & 10 & Cell count & $\begin{array}{c}\text { Naïve CD8+ T cell priming } \\
\text { half saturation }\end{array}$ & $\begin{array}{c}\text { Estimated from } \\
\text { Uncertainty Analysis }\end{array}$ \\
\hline
\end{tabular}




\begin{tabular}{|c|c|c|c|c|}
\hline Parameter & Value & Units & Description & Reference \\
\hline $\mathrm{k}_{1}$ & {$\left[5 \times 10^{-3}, 1\right]$} & day $^{-1}$ & $\begin{array}{l}\text { Naïve } \mathrm{CD} 4+\mathrm{T} \text { cell } \\
\text { recruitment rate }\end{array}$ & $\begin{array}{c}\text { Estimated from } \\
\text { Uncertainty Analysis }\end{array}$ \\
\hline $\mathrm{k}_{2}$ & {$\left[10^{-6}, 10^{-1}\right]$} & day $^{-1}$ & Naïve $\mathrm{CD} 4+\mathrm{T}$ cell Priming rate & $\begin{array}{c}\text { Estimated from } \\
\text { Uncertainty Analysis }\end{array}$ \\
\hline $\mathrm{k}_{3}$ & {$\left[10^{-7}, 10^{-2}\right]$} & day $^{-1}$ & $\begin{array}{l}\text { Central Memory } \mathrm{CD} 4+\mathrm{T} \text { cell } \\
\text { reactivation rate }\end{array}$ & $\begin{array}{c}\text { Estimated from } \\
\text { Uncertainty Analysis }\end{array}$ \\
\hline $\mathrm{k}_{4}$ & {$\left[10^{-2}, 1.2\right]$} & day $^{-1}$ & $\begin{array}{l}\text { Precursor CD4+ T cell } \\
\text { proliferation rate }\end{array}$ & $\begin{array}{c}\text { Estimated from } \\
\text { Uncertainty Analysis }\end{array}$ \\
\hline $\mathrm{k}_{5}$ & {$[0.01,0.75]$} & day $^{-1}$ & $\begin{array}{l}\text { Precursor CD4+ T cell } \\
\text { differentiation to Effector rate }\end{array}$ & $\begin{array}{c}\text { Estimated from } \\
\text { Uncertainty Analysis }\end{array}$ \\
\hline $\mathrm{k}_{6}$ & 0.001 & day $^{-1}$ & $\begin{array}{c}\text { Precursor CD4+ T cell } \\
\text { differentiation to Central Memory }\end{array}$ & $\begin{array}{c}\text { Estimated from } \\
\text { Uncertainty Analysis }\end{array}$ \\
\hline $\mathrm{k}_{7}$ & {$[0.05,0.75]$} & day $^{-1}$ & $\begin{array}{l}\text { Effector CD4+ T cell differentiation } \\
\text { to Effector Memory }\end{array}$ & $\begin{array}{c}\text { Estimated from } \\
\text { Uncertainty Analysis }\end{array}$ \\
\hline $\mathrm{k}_{8}$ & {$[0.1,0.5]$} & day $^{-1}$ & $\begin{array}{l}\text { Central Memory } \mathrm{CD} 4+\mathrm{T} \text { cell } \\
\text { recruitment rate }\end{array}$ & $\begin{array}{c}\text { Estimated from } \\
\text { Uncertainty Analysis }\end{array}$ \\
\hline $\mathrm{k}_{10}$ & {$\left[5 \times 10^{-3}, 1\right]$} & day $^{-1}$ & $\begin{array}{l}\text { Naïve CD8+ T } \\
\text { recruitment cell rate }\end{array}$ & $\begin{array}{c}\text { Estimated from } \\
\text { Uncertainty Analysis }\end{array}$ \\
\hline $\mathrm{k}_{11}$ & {$\left[10^{-6}, 10^{-1}\right]$} & day $^{-1}$ & Naïve CD8+ T cell priming rate & $\begin{array}{c}\text { Estimated from } \\
\text { Uncertainty Analysis }\end{array}$ \\
\hline $\mathrm{k}_{12}$ & {$\left[10^{-7}, 10^{-2}\right]$} & day $^{-1}$ & $\begin{array}{l}\text { Central Memory } \mathrm{CD} 8+\mathrm{T} \text { cell } \\
\text { reactivation rate }\end{array}$ & $\begin{array}{c}\text { Estimated from } \\
\text { Uncertainty Analysis }\end{array}$ \\
\hline $\mathrm{k}_{13}$ & {$\left[10^{-2}, 1.2\right]$} & day $^{-1}$ & $\begin{array}{l}\text { Precursor CD8+ T cell } \\
\text { proliferation rate }\end{array}$ & $\begin{array}{c}\text { Estimated from } \\
\text { Uncertainty Analysis }\end{array}$ \\
\hline $\mathrm{k}_{14}$ & {$[0.01,0.75]$} & day $^{-1}$ & $\begin{array}{c}\text { Precursor CD8+ T cell } \\
\text { differentiation to Effector rate }\end{array}$ & $\begin{array}{c}\text { Estimated from } \\
\text { Uncertainty Analysis }\end{array}$ \\
\hline $\mathrm{k}_{15}$ & 0.001 & day $^{-1}$ & $\begin{array}{c}\text { Precursor CD8+ T cell } \\
\text { differentiation to Central Memory }\end{array}$ & $\begin{array}{c}\text { Estimated from } \\
\text { Uncertainty Analysis }\end{array}$ \\
\hline $\mathrm{k}_{16}$ & {$[0.05,0.75]$} & day $^{-1}$ & $\begin{array}{l}\text { Effector CD8+ T cell differentiation } \\
\text { to Effector Memory }\end{array}$ & $\begin{array}{c}\text { Estimated from } \\
\text { Uncertainty Analysis }\end{array}$ \\
\hline $\mathrm{k}_{17}$ & {$[0.05,0.75]$} & day $^{-1}$ & $\begin{array}{l}\text { Central Memory } \mathrm{CD} 8+\mathrm{T} \text { cell } \\
\text { recruitment rate }\end{array}$ & $\begin{array}{c}\text { Estimated from } \\
\text { Uncertainty Analysis }\end{array}$ \\
\hline$\mu_{1}$ & 0.2 & day $^{-1}$ & Effector CD4+ T cell death rate & {$[19,20,22,23,36]$} \\
\hline$\mu_{2}$ & 0.04 & day $^{-1}$ & $\begin{array}{l}\text { Effector Memory CD4+ T } \\
\text { cell death rate }\end{array}$ & {$[19,20,22,23,36]$} \\
\hline$\mu_{3}$ & 0.2 & day $^{-1}$ & Effector CD8+ T cell death rate & {$[19,20,22,23,36]$} \\
\hline$\mu_{4}$ & 0.04 & day $^{-1}$ & $\begin{array}{l}\text { Effector Memory CD8+ T } \\
\text { cell death rate }\end{array}$ & {$[19,20,22,23,36]$} \\
\hline$\mu_{5}$ & {$[0.1,1]$} & day $^{-1}$ & APC death rate & {$[19,20,22,23,36]$} \\
\hline$\mu_{6}$ & 0.1 & day $^{-1}$ & Precursor CD4+ T cell death rate & {$[19,20,22,23,36]$} \\
\hline$\mu_{7}$ & 0.1 & day $^{-1}$ & Precursor CD8+ T cell death rate & {$[19,20,22,23,36]$} \\
\hline$\mu_{8}^{*}$ & $3.93 \times 10^{-4}$ & day $^{-1}$ & Naïve CD4+ T cell death rate & \\
\hline$\mu_{9}^{*}$ & $2.27 \times 10^{-4}$ & day $^{-1}$ & Naïve CD8+ T cell death rate & \\
\hline$\rho_{1}$ & $3 \times 10^{8}$ & Cell count & Precursor carrying capacity & {$[19,20,22,23,36]$} \\
\hline $\mathrm{Wp}_{4}$ & 0.735 & “” & $\begin{array}{l}\text { Weight factor for Precursor CD4+ T } \\
\text { in CD } 8+\mathrm{T} \text { cell priming }\end{array}$ & $\begin{array}{c}\text { Estimated from } \\
\text { Uncertainty Analysis }\end{array}$ \\
\hline$\xi_{1} *$ & $\xi_{2} \times\left(\mathrm{N}_{\mathrm{Ln}, \mathrm{nc} 4} / \mathrm{N}_{\mathrm{B}, \mathrm{nc} 4}\right) / \alpha$ & day $^{-1}$ & Naïve CD4 Lymph Influx & \\
\hline$\xi_{2}$ & {$[0.6,1]$} & day $^{-1}$ & Naïve CD4 Lymph Efflux & $\begin{array}{c}\text { Estimated from } \\
\text { Uncertainty Analysis }\end{array}$ \\
\hline$\xi_{3}$ & {$[2,5]$} & day $^{-1}$ & Effector CD4 Lymph Efflux & $\begin{array}{c}\text { Estimated from } \\
\text { Uncertainty Analysis }\end{array}$ \\
\hline$\xi_{4} *$ & $\xi_{5} \times\left(\mathrm{CM}_{\mathrm{Ln}, \mathrm{nc} 4} / \mathrm{CM}_{\mathrm{B}, \mathrm{nc} 4}\right) / \alpha$ & day $^{-1}$ & Central Memory CD4 Lymph Influx & \\
\hline$\xi_{5}$ & 0.489 & day $^{-1}$ & Central Memory CD4 Lymph Efflux & $\begin{array}{c}\text { Estimated from } \\
\text { Uncertainty Analysis }\end{array}$ \\
\hline$\xi_{6}$ & {$[2,5]$} & day $^{-1}$ & Effector Memory CD4 Lymph Efflux & $\begin{array}{c}\text { Estimated from } \\
\text { Uncertainty Analysis }\end{array}$ \\
\hline$\xi_{7} *$ & $\xi_{8} \times\left(\mathrm{N}_{\mathrm{Ln}, \mathrm{nc} 8} / \mathrm{N}_{\mathrm{B}, \mathrm{nc} 8}\right) / \alpha$ & day $^{-1}$ & Naïve CD8 Lymph Influx & \\
\hline$\xi_{8}$ & {$[0.6,1]$} & day $^{-1}$ & Naïve CD8 Lymph Efflux & $\begin{array}{c}\text { Estimated from } \\
\text { Uncertainty Analysis }\end{array}$ \\
\hline
\end{tabular}




\begin{tabular}{|c|c|c|c|c|}
\hline Parameter & Value & Units & Description & Reference \\
\hline$\xi_{9}$ & {$[2,5]$} & day $^{-1}$ & Effector CD8 Lymph Efflux & $\begin{array}{c}\text { Estimated from } \\
\text { Uncertainty Analysis }\end{array}$ \\
\hline$\xi_{10} *$ & $\xi_{11} \times\left(\mathrm{CM}_{\mathrm{Ln}, \mathrm{nc} 8} / \mathrm{CM}_{\mathrm{B}, \mathrm{nc} 8}\right) / \alpha$ & day $^{-1}$ & Effector CD8 Lymph Influx & \\
\hline$\xi_{11}$ & {$[2,5]$} & day $^{-1}$ & Central Memory CD8 Lymph Efflux & $\begin{array}{c}\text { Estimated from } \\
\text { Uncertainty Analysis }\end{array}$ \\
\hline$\xi_{12}$ & {$[2,5]$} & day $^{-1}$ & Effector Memory CD8 Lymph Efflux & $\begin{array}{c}\text { Estimated from } \\
\text { Uncertainty Analysis }\end{array}$ \\
\hline proliferationTime & 8 & $\mathrm{~h}$ & $\begin{array}{l}\text { Doubling time for cognate } \\
\mathrm{T} \text { cells in the lung }\end{array}$ & {$[40,71]$} \\
\hline maxDivisions & 4 & -- & $\begin{array}{l}\text { Max number of divisions for } \\
\mathrm{T} \text { cells in the lung }\end{array}$ & {$[40,71]$} \\
\hline$\tau_{\mathrm{T} \gamma-\mathrm{CC}}$ & {$[1,20]$} & \# molecules & $\begin{array}{l}\text { Chemokine threshold } \\
\text { for } \mathrm{T}_{\gamma} \text { recruitment }\end{array}$ & $\begin{array}{c}\text { Estimated from } \\
\text { Uncertainty Analysis }\end{array}$ \\
\hline$\tau_{\mathrm{T} \gamma-\mathrm{TNF}}$ & {$[1,5]$} & \# molecules & $\begin{array}{l}\text { Tumor necrosis factor (TNF) } \\
\text { threshold for } \mathrm{T}_{\gamma} \text { recruitment }\end{array}$ & $\begin{array}{c}\text { Estimated from } \\
\text { Uncertainty Analysis }\end{array}$ \\
\hline$\tau_{\mathrm{TCyt}-\mathrm{CC}}$ & {$[1,20]$} & \# molecules & $\begin{array}{l}\text { Chemokine threshold } \\
\text { for Tcyt recruitment }\end{array}$ & $\begin{array}{c}\text { Estimated from } \\
\text { Uncertainty Analysis }\end{array}$ \\
\hline$\tau_{\mathrm{TCyt}-\mathrm{TNF}}$ & {$[1,5]$} & \# molecules & TNF threshold for Tcyt recruitment & $\begin{array}{c}\text { Estimated from } \\
\text { Uncertainty Analysis }\end{array}$ \\
\hline$\tau_{\text {Treg-CC }}$ & {$[1,10]$} & \# molecules & $\begin{array}{l}\text { Chemokine threshold } \\
\text { for Treg recruitment }\end{array}$ & $\begin{array}{c}\text { Estimated from } \\
\text { Uncertainty Analysis }\end{array}$ \\
\hline$\tau_{\text {Treg-TNF }}$ & {$[1,5]$} & \# molecules & TNF threshold for Treg recruitment & $\begin{array}{c}\text { Estimated from } \\
\text { Uncertainty Analysis }\end{array}$ \\
\hline ProbKillMac & {$[0.05,0.21]$} & probability & Probability of Tcyt to kill Macs & {$[19,20,22,23,36]$} \\
\hline probKillMacCleanly & {$[0.15,0.31]$} & probability & $\begin{array}{l}\text { Probability of Tcyt to kill Macs and } \\
\text { all their intracellular Mtb load }\end{array}$ & {$[19,20,22,23,36]$} \\
\hline probApoptosisFasFasL & {$[0.001,0.02]$} & probability & $\begin{array}{l}\text { Probability of undergoing } \\
\text { apotposis induced by } \mathrm{T} \gamma\end{array}$ & {$[19,20,22,23,36]$} \\
\hline lungExitInterval & {$[6,144]$} & $10 \mathrm{~min}$ & $\begin{array}{c}\text { Time it takes a stimulated } \\
\text { dendritic cell (DC) to exit the lung } \\
\text { through lymphatics }\end{array}$ & {$[19,20,22]$} \\
\hline lymphaticsExitInterval & {$[6,40]$} & $10 \mathrm{~min}$ & $\begin{array}{l}\text { Time a DC takes to traffic through } \\
\text { the lymphatics and reach the } \\
\text { lymph node (LN) }\end{array}$ & {$[19,20,22]$} \\
\hline percentOfMacInitNumber & {$[0.05,0.25]$} & $\begin{array}{l}\% \text {, and used } \\
\text { as probability } \\
\text { as well }\end{array}$ & $\begin{array}{l}\text { Percentages of DCs that populates } \\
\text { the grid initially (calculated as } \\
\text { a percentage of initial resident } \\
\text { macrophages). It is also used for } \\
\text { recruitment on new DC into the } \\
\text { grid, at the time a macrophage } \\
\text { is recruited }\end{array}$ & {$[20,22]$} \\
\hline growthRateIntMtb & {$[1.0029,1.0035]$} & $10 \mathrm{~min}$ & Doubling time of intracellular Mtb & [23] \\
\hline growthRateExtMtb & {$[1.00124,1.0014]$} & $10 \mathrm{~min}$ & Doubling time of extracellular Mtb & [23] \\
\hline
\end{tabular}

\section{Appendix B}

List of all the outcomes of interest analyzed during our uncertainty and sensitivity analysis.

\begin{tabular}{ccc}
\hline Outcome of Interest & Compartment & Definition \\
\hline Inflammation & & \\
\hline 'TotalMr' & Lung & Total Resting Macrophages \\
'TotalDCellMr' & Lung & Total Unstimulated Dendritic Cells \\
'TotalMa' & Lung & Total Activated Macrophages \\
'TotPethot' & Lung & Total Pet Hot reading from the PET-CT scan \\
'NrCaseated' & Lung & Number of caseated compartments in the granuloma \\
'TNF' & Lung & Tumor Necrosis Factor molecues \\
'IL10' & Lung & Interlukin 10 molecules \\
\hline
\end{tabular}




\begin{tabular}{ccc}
\hline Outcome of Interest & Compartment & Definition \\
\hline Infection & & \\
\hline 'TotMtb' & Lung & Total Mycobacterium tuberculosis (Mtb) burden \\
'IntMtb' & Lung & Intracellular Mtb burden \\
'ExtMtb' & Lung & Extracellular Mtb burden \\
'repExtMtb' & Lung & Extracellular replicating Mtb burden \\
'NonReplExtMtb' & Lung & Extracellular non-replicating Mtb burden \\
'TotalMi' & Lung & Total Infected Macrophages \\
'TotalMci' & Lung & Total Chronically Infected Macrophages \\
'TotalDCellMi' & Lung & Total Infected Dendritic Cells \\
'TotalDCellMci' & Lung & Total Chronically Infected Dendritic Cells \\
'LesionSize' & Lung & Diameter of the granuloma lesion \\
\hline
\end{tabular}

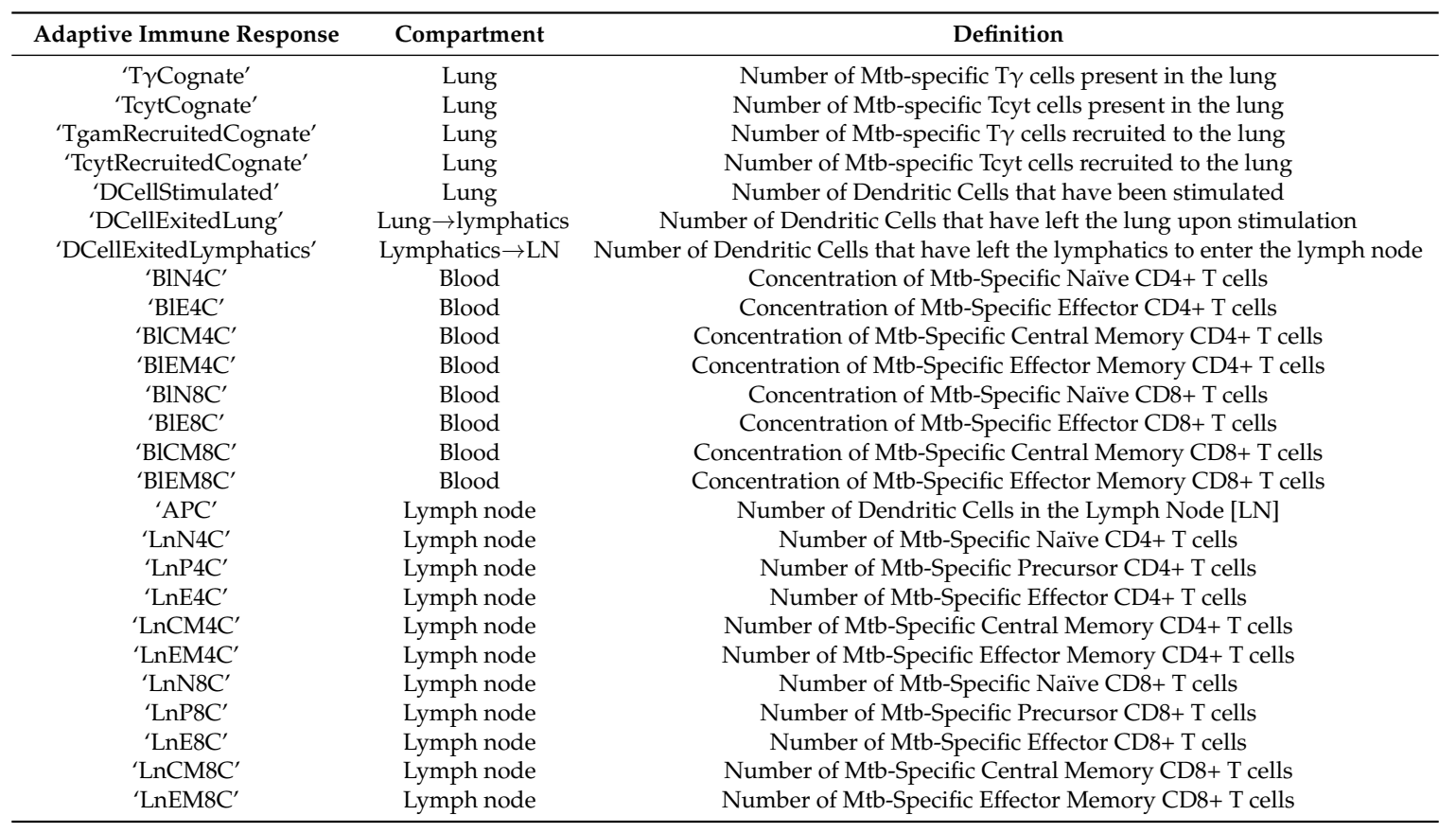

\section{References}

1. World Health Organization. Global Tuberculosis Report 2014; World Health Organization: Geneva, Switzerland, 2014.

2. Mattila, J.T.; Maiello, P.; Sun, T.; Via, L.E.; Flynn, J.L. Granzyme B-expressing neutrophils correlate with bacteria load in granulomas from Mycobacterium tuberculosis-infected cynomolgus macaques. Cell. Microbiol. 2015, 17, 1085-1097. [CrossRef] [PubMed]

3. Barry, C.E., 3rd; Boshoff, H.I.; Dartois, V.; Dick, T.; Ehrt, S.; Flynn, J.; Schnappinger, D.; Wilkinson, R.J.; Young, D. The spectrum of latent tuberculosis: Rethinking the biology and intervention strategies. Nat. Rev. Microbiol. 2009, 7, 845-855. [CrossRef] [PubMed]

4. Redford, P.S.; Murray, P.J.; O'Garra, A. The role of IL-10 in immune regulation during M. tuberculosis infection. Mucosal Immunol. 2011, 4, 261-270. [CrossRef] [PubMed]

5. Geissmann, F.; Manz, M.G.; Jung, S.; Sieweke, M.H.; Merad, M.; Ley, K. Development of monocytes, macrophages, and dendritic cells. Science 2010, 327, 656-661. [CrossRef] [PubMed]

6. Saunders, B.M.; Frank, A.A.; Orme, I.M.; Cooper, A.M. CD4 is required for the development of a protective granulomatous response to pulmonary tuberculosis. Cell. Immunol. 2002, 216, 65-72. [CrossRef]

7. Hao, S.; Baltimore, D. The stability of mRNA influences the temporal order of the induction of genes encoding inflammatory molecules. Nat. Immunol. 2009, 10, 281-288. [CrossRef] [PubMed]

8. Scanga, C.A.; Mohan, V.P.; Yu, K.; Joseph, H.; Tanaka, K.; Chan, J.; Flynn, J.L. Depletion of CD4(+) T cells causes reactivation of murine persistent tuberculosis despite continued expression of interferon gamma and nitric oxide synthase 2. J. Exp. Med. 2000, 192, 347-358. [CrossRef] [PubMed] 
9. Green, A.M.; Difazio, R.; Flynn, J.L. IFN-gamma from CD4 T cells is essential for host survival and enhances CD8 T cell function during Mycobacterium tuberculosis infection. J. Immunol. 2013, 190, 270-277. [CrossRef] [PubMed]

10. Benoit, M.; Desnues, B.; Mege, J.L. Macrophage polarization in bacterial infections. J. Immunol. 2008, 181, 3733-3739. [CrossRef] [PubMed]

11. Chen, C.Y.; Huang, D.; Wang, R.C.; Shen, L.; Zeng, G.; Yao, S.; Shen, Y.; Halliday, L.; Fortman, J.; McAllister, M.; et al. A critical role for CD8 T cells in a nonhuman primate model of tuberculosis. PLoS Pathog. 2009, 5. [CrossRef] [PubMed]

12. Benoit, M.; Barbarat, B.; Bernard, A.; Olive, D.; Mege, J.L. Coxiella burnetii, the agent of Q fever, stimulates an atypical M2 activation program in human macrophages. Eur. J. Immunol. 2008, 38, 1065-1070. [CrossRef] [PubMed]

13. Diedrich, C.R.; Mattila, J.T.; Klein, E.; Janssen, C.; Phuah, J.; Sturgeon, T.J.; Montelaro, R.C.; Lin, P.L.; Flynn, J.L. Reactivation of latent tuberculosis in cynomolgus macaques infected with SIV is associated with early peripheral T cell depletion and not virus load. PLoS ONE 2010, 5. [CrossRef] [PubMed]

14. Kiszewski, A.E.; Becerril, E.; Aguilar, L.D.; Kader, I.T.; Myers, W.; Portaels, F.; Hernandez Pando, R. The local immune response in ulcerative lesions of Buruli disease. Clin. Exp. Immunol. 2006, 143, 445-451. [CrossRef] [PubMed]

15. Bauer, A.L.; Beauchemin, C.A.; Perelson, A.S. Agent-based modeling of host-pathogen systems: The successes and challenges. Inf. Sci. (Ny) 2009, 179, 1379-1389. [CrossRef] [PubMed]

16. Chavali, A.K.; Gianchandani, E.P.; Tung, K.S.; Lawrence, M.B.; Peirce, S.M.; Papin, J.A. Characterizing emergent properties of immunological systems with multi-cellular rule-based computational modeling. Trends Immunol. 2008, 29, 589-599. [CrossRef] [PubMed]

17. Greve, L.; Dyson, S. Saddle fit and management: An investigation of the association with equine thoracolumbar asymmetries, horse and rider health. Equine Vet. J. 2015, 47, 415-421. [CrossRef] [PubMed]

18. Hellweger, F.L.; Clegg, R.J.; Clark, J.R.; Plugge, C.M.; Kreft, J.U. Advancing microbial sciences by individual-based modelling. Nat. Rev. Microbiol. 2016, 14, 461-471. [CrossRef] [PubMed]

19. Marino, S.; El-Kebir, M.; Kirschner, D. A hybrid multi-compartment model of granuloma formation and T cell priming in Tuberculosis. J. Theor. Biol. 2011, 280, 50-62. [CrossRef] [PubMed]

20. Marino, S.; Kirschner, D.E. The human immune response to Mycobacterium tuberculosis in lung and lymph node. J. Theor. Biol. 2004, 227, 463-486. [CrossRef] [PubMed]

21. Marino, S.; Linderman, J.J.; Kirschner, D.E. A multifaceted approach to modeling the immune response in tuberculosis. Wiley Interdiscip. Rev. Syst. Biol. Med. 2011, 3, 479-489. [CrossRef] [PubMed]

22. Marino, S.; Pawar, S.; Fuller, C.L.; Reinhart, T.A.; Flynn, J.L.; Kirschner, D.E. Dendritic cell trafficking and antigen presentation in the human immune response to Mycobacterium tuberculosis. J. Immunol. 2004, 173, 494-506. [CrossRef] [PubMed]

23. Wigginton, J.E.; Kirschner, D. A model to predict cell-mediated immune regulatory mechanisms during human infection with Mycobacterium tuberculosis. J. Immunol. 2001, 166, 1951-1967. [CrossRef] [PubMed]

24. Segovia-Juarez, J.L.; Ganguli, S.; Kirschner, D. Identifying control mechanisms of granuloma formation during M. tuberculosis infection using an agent-based model. J. Theor. Biol. 2004, 231, 357-376. [CrossRef] [PubMed]

25. Ray, J.C.; Flynn, J.L.; Kirschner, D.E. Synergy between individual TNF-dependent functions determines granuloma performance for controlling Mycobacterium tuberculosis infection. J. Immunol. 2009, 182, 3706-3717. [CrossRef] [PubMed]

26. Gammack, D.; Ganguli, S.; Marino, S.; Segovia-Juarez, J.; Kirschner, D.E. Understanding the immune response in tuberculosis using different mathematical models and biological scales. Multiscale Model. Simul. 2005, 3, 312-345. [CrossRef]

27. Cardona, P.J.; Amat, I.; Gordillo, S.; Arcos, V.; Guirado, E.; Diaz, J.; Vilaplana, C.; Tapia, G.; Ausina, V. Immunotherapy with fragmented Mycobacterium tuberculosis cells increases the effectiveness of chemotherapy against a chronical infection in a murine model of tuberculosis. Vaccine 2005, 23, 1393-1398. [CrossRef] [PubMed]

28. Cardona, P.J.; Llatjos, R.; Gordillo, S.; Diaz, J.; Vinado, B.; Ariza, A.; Ausina, V. Towards a ‘human-like' model of tuberculosis: Intranasal inoculation of LPS induces intragranulomatous lung necrosis in mice infected aerogenically with Mycobacterium tuberculosis. Scand. J. Immunol. 2001, 53, 65-71. [CrossRef] [PubMed] 
29. Files for GranSim. Available online: http://malthus.micro.med.umich.edu/GranSim (accessed on 18 October 2016).

30. Rateitschak, K.; Karger, A.; Fitzner, B.; Lange, F.; Wolkenhauer, O.; Jaster, R. Mathematical modelling of interferon-gamma signalling in pancreatic stellate cells reflects and predicts the dynamics of STAT1 pathway activity. Cell Signal. 2010, 22, 97-105. [CrossRef] [PubMed]

31. Braun, D.A.; Fribourg, M.; Sealfon, S.C. Cytokine response is determined by duration of receptor and signal transducers and activators of transcription 3 (STAT3) activation. J. Biol. Chem. 2013, 288, 2986-2993. [CrossRef] [PubMed]

32. Pienaar, E.; Cilfone, N.A.; Lin, P.L.; Dartois, V.; Mattila, J.T.; Butler, J.R.; Flynn, J.L.; Kirschner, D.E.; Linderman, J.J. A computational tool integrating host immunity with antibiotic dynamics to study tuberculosis treatment. J. Theor. Biol. 2015, 367, 166-179. [CrossRef] [PubMed]

33. Marino, S.; Sud, D.; Plessner, H.; Lin, P.L.; Chan, J.; Flynn, J.L.; Kirschner, D.E. Differences in reactivation of tuberculosis induced from anti-TNF treatments are based on bioavailability in granulomatous tissue. PLoS Comput. Biol. 2007, 3, 1909-1924. [CrossRef] [PubMed]

34. Fallahi-Sichani, M.; Flynn, J.L.; Linderman, J.J.; Kirschner, D.E. Differential risk of tuberculosis reactivation among anti-TNF therapies is due to drug binding kinetics and permeability. J. Immunol. 2012, 188, 3169-3178. [CrossRef] [PubMed]

35. Marino, S.; Fallahi-Sichani, M.; Linderman, J.J.; Kirschner, D.E. Mathematical Models of Anti-TNF Therapies and their Correlation with Tuberculosis. In Antibody-Mediated Drug Delivery Systems; John Wiley \& Sons, Inc.: Hoboken, NJ, USA, 2012; pp. 83-104.

36. Marino, S.; Gideon, H.P.; Gong, C.; Mankad, S.; McCrone, J.T.; Lin, P.L.; Linderman, J.J.; Flynn, J.L.; Kirschner, D.E. Computational and Empirical Studies Predict Mycobacterium tuberculosis-Specific T Cells as a Biomarker for Infection Outcome. PLoS Comput. Biol. 2016, 12. [CrossRef] [PubMed]

37. Marino, S.; Hogue, I.B.; Ray, C.J.; Kirschner, D.E. A methodology for performing global uncertainty and sensitivity analysis in systems biology. J. Theor. Biol. 2008, 254, 178-196. [CrossRef] [PubMed]

38. Cilfone, N.A.; Perry, C.R.; Kirschner, D.E.; Linderman, J.J. Multi-scale modeling predicts a balance of tumor necrosis factor-alpha and interleukin-10 controls the granuloma environment during Mycobacterium tuberculosis infection. PLoS ONE 2013, 8. [CrossRef] [PubMed]

39. Fallahi-Sichani, M.; El-Kebir, M.; Marino, S.; Kirschner, D.E.; Linderman, J.J. Multiscale computational modeling reveals a critical role for TNF-alpha receptor 1 dynamics in tuberculosis granuloma formation. J. Immunol. 2011, 186, 3472-3483. [CrossRef] [PubMed]

40. Gong, C.; Linderman, J.J.; Kirschner, D. Harnessing the heterogeneity of T cell differentiation fate to fine-tune generation of effector and memory T cells. Front. Immunol. 2014, 5. [CrossRef] [PubMed]

41. Fallahi-Sichani, M.; Kirschner, D.E.; Linderman, J.J. NF-kappaB Signaling Dynamics Play a Key Role in Infection Control in Tuberculosis. Front. Physiol. 2012, 3. [CrossRef] [PubMed]

42. Cilfone, N.A.; Ford, C.B.; Marino, S.; Mattila, J.T.; Gideon, H.P.; Flynn, J.L.; Kirschner, D.E.; Linderman, J.J. Computational Modeling Predicts IL-10 Control of Lesion Sterilization by Balancing Early Host Immunity-Mediated Antimicrobial Responses with Caseation during Mycobacterium tuberculosis Infection. J. Immunol. 2015, 194, 664-677. [CrossRef] [PubMed]

43. Marino, S.; Cilfone, N.A.; Mattila, J.T.; Linderman, J.J.; Flynn, J.L.; Kirschner, D.E. Macrophage Polarization Drives Granuloma Outcome during Mycobacterium tuberculosis Infection. Infect. Immun. 2015, 83, 324-338. [CrossRef] [PubMed]

44. Cilfone, N.A.; Kirschner, D.E.; Linderman, J.J. Strategies for efficient numerical implementation of hybrid multi-scale agent-based models to describe biological systems. Cell. Mol. Bioeng. 2015, 8, 119-136. [CrossRef] [PubMed]

45. Banchereau, J.; Briere, F.; Caux, C.; Davoust, J.; Lebecque, S.; Liu, Y.J.; Pulendran, B.; Palucka, K. Immunobiology of dendritic cells. Annu. Rev. Immunol. 2000, 18, 767-811. [CrossRef] [PubMed]

46. Banchereau, J.; Steinman, R.M. Dendritic cells and the control of immunity. Nature 1998, 392, $245-252$. [CrossRef] [PubMed]

47. Demangel, C.; Britton, W.J. Interaction of dendritic cells with mycobacteria: Where the action starts. Immunol. Cell Biol. 2000, 78, 318-324. [CrossRef] [PubMed]

48. Mihret, A. The role of dendritic cells in Mycobacterium tuberculosis infection. Virulence 2012, 3, 654-659. [CrossRef] [PubMed] 
49. Bodnar, K.A.; Serbina, N.V.; Flynn, J.L. Fate of Mycobacterium tuberculosis within murine dendritic cells. Infect. Immun. 2001, 69, 800-809. [CrossRef] [PubMed]

50. Mazzini, E.; Massimiliano, L.; Penna, G.; Rescigno, M. Oral tolerance can be established via gap junction transfer of fed antigens from CX3CR1(+) macrophages to CD103(+) dendritic cells. Immunity 2014, 40, 248-261. [CrossRef] [PubMed]

51. Janeway, C. Immunology: The Immune System in Health and Disease, 6th ed.; Garland Science Publishing: New York, NY, USA, 2005.

52. Lin, P.L.; Coleman, T.; Carney, J.P.; Lopresti, B.J.; Tomko, J.; Fillmore, D.; Dartois, V.; Scanga, C.; Frye, L.J.; Janssen, C.; et al. Radiologic responses in cynomolgous macaques for assessing tuberculosis chemotherapy regimens. Antimicrob. Agents Chemother. 2013. [CrossRef] [PubMed]

53. Coleman, M.T.; Maiello, P.; Tomko, J.; Frye, L.J.; Fillmore, D.; Janssen, C.; Klein, E.; Lin, P.L. Early Changes by (18)Fluorodeoxyglucose positron emission tomography coregistered with computed tomography predict outcome after Mycobacterium tuberculosis infection in cynomolgus macaques. Infect. Immun. 2014, 82, 2400-2404. [CrossRef] [PubMed]

54. Uncertainty and Sensitivity Analysis. Available online: http://malthus.micro.med.umich.edu/lab/ usanalysis.html (accessed on 18 October 2016).

55. Blower, S.M.; Dowlatabadi, H. Sensitivity and Uncertainty Analysis of Complex-Models of Disease Transmission-An HIV Model, as an Example. Int. Stat. Rev. 1994, 62, 229-243. [CrossRef]

56. Greenland, S. Sensitivity analysis, Monte Carlo risk analysis, and Bayesian uncertainty assessment. Risk Anal. 2001, 21, 579-583. [CrossRef] [PubMed]

57. Kimmick, G.G.; Shelton, B.J.; Case, L.D.; Cooper, M.R.; Muss, H.B. Long-term follow-up of a phase II trial studying a weekly doxorubicin-based multiple drug adjuvant therapy for stage II node-positive carcinoma of the breast. Breast Cancer Res. Treat. 2002, 72, 233-243. [CrossRef] [PubMed]

58. Sanchez, M.A.; Blower, S.M. Uncertainty and sensitivity analysis of the basic reproductive rate. Tuberculosis as an example. Am. J. Epidemiol. 1997, 145, 1127-1137. [CrossRef] [PubMed]

59. Gammack, D.; Doering, C.R.; Kirschner, D.E. Macrophage response to Mycobacterium tuberculosis infection. J. Math. Biol. 2004, 48, 218-242. [CrossRef] [PubMed]

60. Ganguli, S.; Gammack, D.; Kirschner, D.E. A metapopulation model of granuloma formation in the lung during infection with mycobacterium tuberculosis. Math. Biosci. Eng. 2005, 2, 535-560. [PubMed]

61. Marino, S.; Beretta, E.; Kirschner, D.E. The role of delays in innate and adaptive immunity to intracellular bacterial infection. Math. Biosci. Eng. 2007, 4, 261-288. [CrossRef] [PubMed]

62. Helton, J.C.; Johnson, J.D.; Sallaberry, C.J.; Storlie, C.B. Survey of sampling-based methods for uncertainty and sensitivity analysis. Reliab. Eng. Syst. Saf. 2006, 91, 1175-1209. [CrossRef]

63. Fallahi-Sichani, M.; Marino, S.; Flynn, J.L.; Linderman, J.J.; Kirschner, D.E. A systems biology approach for understanding granuloma formation and function in tuberculosis. In Systems Biology of Tuberculosis; McFadden, J., Beste, D.J.V., Kierzek, A.M., Eds.; Springer: Berlin/Heidelberg, Germany, 2013.

64. Fallahi-Sichani, M.; Schaller, M.A.; Kirschner, D.E.; Kunkel, S.L.; Linderman, J.J. Identification of key processes that control tumor necrosis factor availability in a tuberculosis granuloma. PLoS Comput. Biol. 2010, 6. [CrossRef] [PubMed]

65. Chen, R.Y.; Dodd, L.E.; Lee, M.; Paripati, P.; Hammoud, D.A.; Mountz, J.M.; Jeon, D.; Zia, N.; Zahiri, H.; Coleman, M.T.; et al. PET/CT imaging correlates with treatment outcome in patients with multidrug-resistant tuberculosis. Sci. Transl. Med. 2014, 6. [CrossRef] [PubMed]

66. Flynn, J.L.; Chan, J.; Triebold, K.J.; Dalton, D.K.; Stewart, T.A.; Bloom, B.R. An essential role for interferon gamma in resistance to Mycobacterium tuberculosis infection. J. Exp. Med. 1993, 178, 2249-2254. [CrossRef] [PubMed]

67. Rozot, V.; Vigano, S.; Mazza-Stalder, J.; Idrizi, E.; Day, C.L.; Perreau, M.; Lazor-Blanchet, C.; Petruccioli, E.; Hanekom, W.; Goletti, D.; et al. Mycobacterium tuberculosis-specific CD8+ T cells are functionally and phenotypically different between latent infection and active disease. Eur. J. Immunol. 2013, 43, 1568-1577. [CrossRef] [PubMed]

68. Shang, S.; Siddiqui, S.; Bian, Y.; Zhao, J.; Wang, C.R. Nonclassical MHC Ib-restricted CD8+ T Cells Recognize Mycobacterium tuberculosis-Derived Protein Antigens and Contribute to Protection against Infection. PLoS Pathog. 2016, 12. [CrossRef] [PubMed] 
69. Sud, D.; Bigbee, C.; Flynn, J.L.; Kirschner, D.E. Contribution of CD8+ T cells to control of Mycobacterium tuberculosis infection. J. Immunol. 2006, 176, 4296-4314. [CrossRef] [PubMed]

70. Bellone, M.; Calcinotto, A. Ways to enhance lymphocyte trafficking into tumors and fitness of tumor infiltrating lymphocytes. Front. Oncol. 2013, 3. [CrossRef] [PubMed]

71. Gong, C.; Mattila, J.T.; Miller, M.; Flynn, J.L.; Linderman, J.J.; Kirschner, D. Predicting lymph node output efficiency using systems biology. J. Theor. Biol. 2013, 335, 169-184. [CrossRef] [PubMed]

72. Fletcher, H.A.; Schrager, L. TB vaccine development and the End TB Strategy: Importance and current status. Trans. R. Soc. Trop. Med. Hyg. 2016, 110, 212-218. [CrossRef] [PubMed]

73. Palucka, K.; Banchereau, J. Cancer immunotherapy via dendritic cells. Nat. Rev. Cancer 2012, 12, $265-277$. [CrossRef] [PubMed]

74. Steinman, R.M. Dendritic cells and the control of immunity: Enhancing the efficiency of antigen presentation. Mt. Sinai J. Med. 2001, 68, 160-166. [PubMed]

75. Lindestam Arlehamn, C.S.; Lewinsohn, D.; Sette, A. Antigens for CD4 and CD8 T cells in tuberculosis. Cold Spring Harb. Perspect. Med. 2014, 4. [CrossRef] [PubMed]

76. Lindestam Arlehamn, C.S.; Paul, S.; Mele, F.; Huang, C.; Greenbaum, J.A.; Vita, R.; Sidney, J.; Peters, B.; Sallusto, F.; Sette, A. Immunological consequences of intragenus conservation of Mycobacterium tuberculosis T-cell epitopes. Proc. Natl. Acad. Sci. USA 2015, 112, E147-E155. [CrossRef] [PubMed]

77. Lindestam Arlehamn, C.S.; Sette, A. Definition of CD4 Immunosignatures Associated with MTB. Front. Immunol. 2014, 5. [CrossRef] [PubMed]

(C) 2016 by the authors; licensee MDPI, Basel, Switzerland. This article is an open access article distributed under the terms and conditions of the Creative Commons Attribution (CC-BY) license (http://creativecommons.org/licenses/by/4.0/). 